IZA DP No. 4989

Short-Time Compensation and Establishment Exit: An Empirical Analysis with French Data

Oana Calavrezo

Richard Duhautois

Emmanuelle Walkowiak

June 2010 


\title{
Short-Time Compensation and Establishment Exit: An Empirical Analysis with French Data
}

\author{
Oana Calavrezo \\ University of Orléans - LEO \\ and IZA
}

Richard Duhautois

CEE, University of Paris-Est Marne-la-Vallée

and CREST

\author{
Emmanuelle Walkowiak \\ University of Paris12 - ERUDITE \\ and CEE
}

Discussion Paper No. 4989

June 2010

IZA

P.O. Box 7240

53072 Bonn

Germany

Phone: +49-228-3894-0

Fax: +49-228-3894-180

E-mail: iza@iza.org

Any opinions expressed here are those of the author(s) and not those of IZA. Research published in this series may include views on policy, but the institute itself takes no institutional policy positions.

The Institute for the Study of Labor (IZA) in Bonn is a local and virtual international research center and a place of communication between science, politics and business. IZA is an independent nonprofit organization supported by Deutsche Post Foundation. The center is associated with the University of Bonn and offers a stimulating research environment through its international network, workshops and conferences, data service, project support, research visits and doctoral program. IZA engages in (i) original and internationally competitive research in all fields of labor economics, (ii) development of policy concepts, and (iii) dissemination of research results and concepts to the interested public.

IZA Discussion Papers often represent preliminary work and are circulated to encourage discussion. Citation of such a paper should account for its provisional character. A revised version may be available directly from the author. 
IZA Discussion Paper No. 4989

June 2010

\section{ABSTRACT}

\section{Short-Time Compensation and Establishment Exit: An Empirical Analysis with French Data*}

According to the French law, the short-time compensation (STC) program aims at avoiding redundancies during short-term downturns. Even if it does not shield establishments from redundancies (Calavrezo, Duhautois and Walkowiak, 2009a), STC can preserve an establishment's survival. This paper studies the relationship between STC and establishment exit over the period 2000-2005. We merge six data sets and we test the relationship between STC and establishment exit with propensity score matching techniques. Our results show that, on average, the year after establishments implement STC, they exit the market more intensely than establishments that do not use the program.

JEL Classification: J20, J63, C14

Keywords: short-time compensation, establishment exit, selection bias, propensity score matching

Corresponding author:

Oana Calavrezo

Laboratoire d'Economie d'Orléans (LEO)

Faculté de Droit, d'Economie et de Gestion

Rue de Blois, BP6739

45067 Orléans, CEDEX 2

France

E-mail: oana.calavrezo@etu.univ-orleans.fr

\footnotetext{
" This paper is a prolongation of a project financed by the Statistical Department of the French Labor Ministry (DARES). Data availability: Final sample is available on request from the authors and the initial databases can be requested from the institutions that produce them. At the moment of writing this paper, Oana Calavrezo was a member of the Centre d'Etudes de l'Emploi (CEE).
} 


\section{Introduction}

According to French the law, the short-time compensation (STC) program is an employment protection device because it aims to avoid redundancies during times of shortterm economic downturn or exceptional circumstances (for instance, disasters). Employers applying STC can temporarily reduce employee hours below the legal working time (for the entire establishment or a particular department within the establishment) or eliminate some or all of an employee's job duties. STC allows employees to maintain a contractual bond with their employer. They receive a compensation for their wage loss that is partly paid by the State. STC exists under different forms in most developed countries: for example, the "Cassa Integrazione Guadagni" in Italy, the "Kurzarbeitergeld" in Germany, the "Short-Time Compensation Program" in the United States, the "Work-Sharing Program" in Canada and the "Short-time Working" device in the United Kingdom. In France, the exact name of the device is "Chômage partiel" (partial unemployment). Nevertheless, in this paper, we decide to use the US term. Before the recent economic crisis, even if the STC program was more frequently used in Europe than in North America, it appeared in all countries as a "rare phenomenon." On average, between 1995 and 2005, STC authorizations affected nearly 1\% of French establishments and $2 \%$ of employees in the private sector, excluding agriculture (Calavrezo et al., 2009b). During the 1980 's in the US, there was similarly low STC participation, limited to less than $1 \%$ of employers. Since 2008, the economic crisis has amplified the use of STC programs, especially in Europe.

From a theoretical perspective, the international literature identifies two co-existing STC roles (a security role and a flexibility role) that differentiate North American and continental European systems (see the three main papers on this topic: Van Audenrode, 1994; Houseman and Abraham, 1993; Burdett and Wright, 1989). 
Calavrezo et al. (2009b) investigate the flexibility role of STC between 1995 and 2005 in France. Working time reduction (WTR) is a flexibility device with the initial objective of reducing unemployment through work-sharing. The most recent French WTR laws, in place from 1996 to 2002, provided for the implementation of working time devices, through which firms could use flexibility instruments that allow firms to use employee hours for varying tasks. The STC decree of June $28^{\text {th }}, 2001$ was directly related to the WTR implementation. Since 2001, establishments have had to place a priority on the use of flexible working hours associated with WTR. Calavrezo et al. (2009b) show a "substitution" effect between WTR and STC over the 1995-2005 period. They quantify the average decrease in STC authorized days. Indeed, the flexibility part of the STC program seems to have collapsed: until 2000, STC was inversely correlated to economic growth, and after 2000, firms could no longer use STC as an internal flexibility instrument. This suggests that WTR has refocused the STC program away from its initial role of retaining employees.

Consequently, the following question concerning STC recourse is proposed: is STC really a protection device? The empirical analysis of the security role of STC is focused on its relationship to redundancies. We can analyze the relationship between STC and layoffs through three distinct experiences: the European experience (Vroman, 1992), the US experience (Needels et al., 1997) and the Canadian experience (the Ekos research, 1993). On the whole, even if researchers have found that firms in both American and European systems are likely to use some combination of hour reductions and layoffs, the implications of STC on redundancies remains unclear. In a recent study, Calavrezo et al. (2009a) analyze the effect of the French STC program on redundancies using panel data models with a sample selection, endogenous explanatory variables and unobserved heterogeneity. Calavrezo et al. (2009a) work with an unbalanced panel of more than 36,000 French establishments with at least 50 employees. Their results indicate that STC seems to significantly increase the number of 
redundancies or the probability of layoffs. The authors state that STC seems to be inefficient according to this employment protection criterion. Nevertheless, it is not possible, for instance, to conclude definitively that STC is totally inefficient in terms of employee protection. Even if STC cannot stop redundancies, it perhaps can prevent establishment exit.

For this reason, this paper questions the STC program's efficiency within French establishments by investigating the relationship between the STC recourse and establishment exit behavior between 2000 and 2005. The contribution of this work is twofold. First, empirical analyses on the French STC program are very scarce in the literature; our topic is quite original, especially in terms of the evaluation of a public policy device. Second, we use a rich dataset.

The use of STC among French establishments is not randomly distributed. Thus, selection can be a potential problem because establishments that choose to have STC authorizations might do it as a consequence of their internal strategy. To analyze the effect of the French STC program on establishment exit and to control for selection bias, we implement a propensity score matching methodology. Different models are estimated on six annual samples obtained from the matching of six data sources that contain more than 550,000 observations. Our main result indicates that the year after establishments implement STC, they exit the market more intensely than those exiting establishments that do not use the program.

The remainder of the paper is organized as follows. The second Section describes STC regulations in France. The third Section presents a short review of the literature on the relationship between STC and establishment exit. The fourth Section presents the data. The fifth Section outlines our econometric approach and the sixth Section presents our findings. Finally, the conclusion in the seventh Section discusses the efficiency of the STC program in France. 


\section{STC regulations in France}

The French STC program is a legal instrument that aims at protecting employment and preventing redundancies in cases of exceptional circumstances, by allowing firms to temporarily reduce working time or suspend their business activities. STC can be applied for the following reasons: downturns in economic cycles; difficulties in the acquisition of raw materials or energy; transformation, restructuring or modernization of the firm; and exceptional natural disasters, among other types of difficulties. According to the law, the instrument should be used as a temporary tool.

STC can be considered a preventive economic assistance device in the sense that its main objective is to prevent permanent layoffs of employees in situations of temporary economic difficulties. Employees on STC continue to keep their contractual bond with the employer. A compensation system exists in order to indemnify employees' salary losses due to STC.

The STC regulation has changed twice recently: the first change occurred in 2001 after the implementation of the working time reduction policy, and the second change occurred in 2008-2009 due to the economic crisis. As our period of analysis is 2000-2005, we exclusively concentrate on the description of the STC regulation before 2008.

The decree of June $28^{\text {th }}, 2001$ presents the STC regulation in connection with the WTR policy. In fact, STC recourse became conditioned by working time reduction policy application types. The role of this binding command is to refocus STC on its primary function of supporting employees in employment if the establishment confronts a short-term economic downturn. By implementing the working time reduction policy, overtime and STC no longer represent the only two solutions for an establishment wishing to adapt to the fluctuations of 
activity. After the implementation of the STC binding command, establishments must use one of the devices related to the working time reduction policy.

The binding command of 2001 tries to clarify STC applicable procedures by changing three dimensions of the STC regulation: compensation (Section 2.1), allocation (Section 2.2) and refunds (Section 2.3).

\subsection{Compensation}

The binding command modifies three levels of the STC compensation: the number of compensated hours, the amount of government support and the creation of a specific quota of compensated hours.

In firms with fixed working hours, compensated hours are calculated as the difference between the number of hours that are supposed to be worked and the number of hours effectively worked during the month. With the decrease in legal working hours, the binding command of 2001 stipulates that STC is activated when hours worked are less than 35 hours per week, or below collective working hours (if it is inferior to the legal weekly limit). The binding command also defines the method for calculating compensated hours for the different devices of the working time reduction implementation. Thus the compensation varies according to the rules of WTR organization, for example, modulation of worked hours or "RTT days". Some "unworked" hours might not be compensated, depending on the form of implementation of the working time reduction policy.

The minimum hourly STC compensation was established on February $21^{\text {st }}, 1968$. It is at least equal to $50 \%$ of the hourly gross pay. It corresponds to 4.42 euros per hour of STC compensation. The compensation for each hour on STC contains two elements. The first one is government support. The binding command of June $28^{\text {th }}, 2001$ establishes a shifting rate for this support, according to firm size. This support rate didn't depend on firm size before the 
reform. Therefore, in firms with more than 250 employees, the government support is 2.13 euros per hour. For other firms, the rate is 2.44 euros per hour. A lower STC compensation rate for big firms with at least 250 employees can be explained by the fact that big firms can more easily allocate working hours. When strong threats to employment exist, the government can pay a higher compensation rate. In 2005, government spending on STC amounted to 16.6 million euros and generally fluctuated around 20 million euros during the years before 2005 . The second element is support paid by the employer, which is the difference between the total amount of each STC hour (4.42 euros) and the government's subsidy. In general, the amount equals 1.98 euros per hour for firms with less than 250 employees and equals 2.29 euros per hour otherwise. The STC compensation is exempted of from employer social contribution taxes, but is subjected to the supplementary social security contribution and to the contribution to the repayment of social security debt.

Since the $10^{\text {th }}$ of April, 2001, the State has been refunding firms within the maximum quota of 600 STC hours per employee per year, for all professional branches. The binding command modifies the law, such that in cases where STC funds are used to modernize facilities and firm's buildings, the quota is lowered to 100 hours. This number of hours is ascribed from the total quota of compensated hours. This change in the legislation was made because using STC to modernize facilities was sometimes contrary to the intentions of the measure: this kind of situation might lead to long periods of interruption of the business activities of the firm, which could result in the firm reaching total (maximum) $\mathrm{STC}^{1}$, at which point work contracts end.

\footnotetext{
${ }^{1}$ Total STC is a special situation of STC in which an employee is on STC more than four consecutive weeks. At that point, the work contract ends.
} 


\subsection{Allocation}

The 2001 binding command contains a major change in terms of the allocation of STC $^{2}$. Firms that wish to take advantage of STC have to consult the plant's works council and then apply for an authorization with the French administration at the "department level"3. Asking for STC authorizations was not compulsory before the 2001 binding command. After using STC, employers must address a request for compensation to the French administration. On the other hand, the binding command stipulates that in case of inclement weather, the demand can be registered 30 days after the phenomenon. When the administration accepts the demand, each month the firm must send the administration the amount to be reimbursed (firms pay the employee the entire amount). The binding command provides a special procedure in the case where firms use modulating hours. In this special case, employers should inform the administration at the end of the year after having established accounting statements for modulating hours. If the firm does not comply with these procedures or if the administration rejects the request, the employer must pay "standard" wages.

\subsection{Refunds}

After the change in the STC law, refund procedures contain new elements specifically related to the different forms of working time reduction implementation. The firm must indicate the main structure for allocation of work hours and must inform the administration if executives or migrant workers that have special working hour conditions are in the firm. In the case of using modulating hours, the firm has to provide a work schedule for each employee once the accounting statement for modulating hours has been made.

\section{STC and establishment exit: a literature review}

\footnotetext{
${ }^{2}$ Some categories of employees are not eligible for STC benefits (for example, seasonally unemployed workers).

${ }^{3}$ In France, the equivalent of the American county is called a "départment".
} 
In the economic literature, the relationship between STC and establishment exit is not addressed theoretically or empirically. The only mention to this topic is presented by Blyton (1985). The author makes the following hypothesis: using STC during a sustained economic recession might delay an employer's decisions, which can jeopardize the firm's chances to survive in the long run. The literature on STC is relatively scarce in France. Recently, Calavrezo (2009) presented a complete description of the functionality of STC between 1995 and 2005 in France. In the same vein, empirical studies concerning the effect of public policy devices on establishment exit or establishment survival are especially less developed, as related data is missing. Our description of the review of the literature is two-fold: on the one hand, we briefly describe analyses on the efficiency of STC in terms of employment protection (Section 3.1); on the other hand, we present some papers that underscore the relationship between public policy devices and establishment survival (Section 3.2).

\subsection{STC efficiency in terms of employment protection}

The international literature is both theoretically and empirically focused on STC's employment protection role (Wright, 1991; Abowd and Allain, 1997; Burdett and Wright, 1989; Needels et al., 1997; Gray, 1998). Indeed, most of these papers study the effect of STC on redundancies. They show that STC's effect is not identical among countries and even within the same country. In France, the few theoretical and/or empirical papers emphasize contrasting results with respect to the functions of the data, the period of analysis or the methods used. Abraham and Houseman (1994) and Gray (1998) show a "positive" effect of STC on redundancies. On the other hand, Calavrezo et al. (2009a) analyze the relationship between STC authorizations and redundancies for establishments with at least 50 employees during the period 1996-2004. They show that establishments that use STC more intensively lay off more employees. There are several ways to interpret this finding. The authors suppose 
that the resort to STC authorizations would be the ultimate (inefficient) solution before layoffs. From this point of view, STC authorizations and redundancies might complement each other in the face of economic difficulties. Another possible interpretation is that the STC program is a policy used to accompany establishments in structural decline (even if this is normally forbidden by law). These authors also consider that establishments would resort to STC to calm social tensions before a planned redundancy scheme, or to reassure the shareholders, as using STC might represent a sort of a guarantee from the State. Whatever the true interpretation, the STC program does not fulfill its role of protecting French establishments (with at least 50 employees) that face strong economic difficulties from redundancies. Nevertheless, this result cannot be interpreted as a signal of complete inefficiency of STC in terms of employment protection. Additional analysis is needed. For this reason, our paper studies the relationship between the use of STC and establishment exit. Even if STC does not protect all employees from redundancy, it can nevertheless assure the survival of the establishment and in this way, protect the remaining employees: in this case, establishment exit can be seen as an extreme case of redundancy.

\subsection{The effects of public policy devices on establishment exit}

Since the 1990's, the economic literature on firm survival has strongly developed (especially with the emergence of data permitting a better understanding of firm survival) and a particular attention has been paid to new firms entering the market (especially small firms).

Firm survival is the conceptual opposite of firm exit. In a literature review, Caves (1998) describes the main determinants of the probability of firm survival. Firm features, such as age, size, and innovation (Dunne et al., 1989; Geroski, 1995; Agarwal and Gort, 1999), or entrepreneurial characteristics, such as sex, age, and professional trajectory before the creation of the firm, are the main determinants of firm survival. Papers analyzing the impact 
of public policy devices on firm survival generally deal with newly created firms and focus inevitably on small firms. Moreover, some of the literature studies the effects of government support for firm creation, especially firm creation designed for unemployed people (for Germany, Pféiffer and Reize, 2000; for young entrepreneurs in Italy, Battistin et al., 2001). Gu et al. (2008) survey the main papers on public (and private) policy devices for small firms in the United States. Their analysis emphasizes the difficulty of measuring the impact of financial support on different firm performance indicators. This is due to the existence of very limited data and very simple techniques used in previous studies. Gu et al. (2008) encourage the use of experimental and quasi-experimental methods.

Our approach is slightly different. Generally, the literature analyzes the effect of public policy devices for encouraging firm creation and assuring newly created firm survival. In our case, we use establishments of all ages (newly created or old establishments) in an a priori economic downturn. We control exclusively for establishment and firm characteristics. Our data sources allow for a good identification of firm exit. Nevertheless, our analysis is close to the literature in terms of the methodology used. We use propensity score matching techniques, which are mostly recommended for this type of analysis.

\section{$4 \quad$ Data}

To assess the impact of participation in the STC French program on establishment exit between 2000 and 2005, we use six different data sources. We construct for each year a different file. Finally, we work with six different files, according to the year. Some administrative data sets contain supplementary information on establishments or on firms to which establishments belong.

First, we use monthly STC authorization databases. They are produced by the Departmental Directions of Work and Employment and by the Statistical Department of the 
French Labor Ministry. When facing a strong economic downturn, an employer can request a specified number of STC days. If the request is justifiable, the Departmental Directions of Work and Employment provides an authorization for a specified number of STC days. The files we use give information about the STC authorizations obtained by French establishments between 1995 and 2005. The authorized STC imperfectly measures the actual STC compensation received by establishments, for which they receive financial compensation from the State. Indeed, some establishments can decide not to use STC authorized days. In the database, the number of compensated days is not available at establishment or firm level. Thus we measure the number of authorized STC days. It is the maximum number of days to be compensated and it represents an indicator of business expectations. We analyze the STC behavior at the establishment level with yearly indicators. From these databases, we constituted an exhaustive STC panel. It covers more than 93,000 French establishments of all industries, which had at least one STC authorization between 1995 and 2005. Finally, we retain for our analysis only one measure of STC: for each establishment $i$ and for each year $t$ we construct a dummy variable indicating the participation in the STC program (denoted $\left.S T C_{i t}\right)$.

\section{[Insert Table 1]}

Second, we use the SIREN file, which is an administrative database produced by the French National Institute of Statistics indicating the status of French establishments in August 2007 (establishments are either active or have disappeared); it also gives information on the date of creation of establishments. This file permits us to calculate the age of the establishment (a continuous variable denoted $A G E_{i t}{ }^{4}$ ) and six exit dummy indicators (see table 1). We use these establishment exit variables to control for potential lagged effects of

\footnotetext{
${ }^{4}$ This variable is calculated as the difference between the year of interest and the year of creation of the firm. We do not take into account the month of creation of the establishment.
} 
STC recourse. With this data source, an establishment exit represents all types of suspension of activity in French territory: establishment shutdowns (for economic reasons, without appealing to the courts for bankruptcy; situations in which the establishment finds a buyer without appealing to the courts), establishment failure (with a court-mandated recourse) or other situations in which the establishment is involved in a process of merger and acquisition (M\&A). Nevertheless, the situation of M\&A does not correspond exactly to the actual disappearance of an establishment and we must take into account this aspect when merging data sets. For each year, we construct four classes of establishment age, each corresponding to a quartile of the establishment age distribution. Finally, in our regressions we introduce only the dummy variable corresponding to the oldest establishments (the dummy variable for the fourth quartile of the establishment age distribution).

Third, we use annual administrative data sources relating to the establishments' unemployment insurance systems and covering the 1995-2003 period: the UNEDIC files. These give information about the size of the establishment $S I Z E_{i t}$ (a continuous variable that indicates the number of employees in the establishment); the establishment's industry $\operatorname{INDUSTRY}_{i t}$ (which is captured by 14 dummy variables corresponding to the main 14 aggregated French industries, excepting agriculture and the public sector administration); and the number of women in the establishment $\left(W O M E N_{i t}\right)$. For the $W O M E N_{i t}$ variable, we calculate the percentage of women in the establishment and we introduce the quartiles of this ratio in our estimations by taking as a reference the first quartile. For industry dummies, the industry's "education, health and social action" is our reference in the econometric model.

Fourth, additional information is obtained from the databases of the firms to which establishments belong (the FICUS files). They cover the period 1994-2005. We retain the following two firm indicators: the firm size $\left(F I R M_{-} S I Z E_{i t}\right)$ and the firm's value added 
$\left(V A_{i t}\right)$. We calculate two indicators of the economic health of the firm to which the establishment belongs: the value-added variation rate $\left(V a r_{-} V A_{i t}=\frac{V A_{i t}-V A_{i t-1}}{V A_{i t-1}}\right)$ and the apparent labor productivity ratio $\left(L P_{i t}=\frac{V A_{i t}}{F I R M_{-} S I Z E_{i t}}\right)$. For the variable VAR_VA, we calculate its values at time $t$ and its values lagged by one year $(t-1)$. For the $L P$ variable, we only calculate its values at time $t$. Since 1998, the FICUS files have contained more information: the legal status of the firm (we construct a legal status variable $L S_{i t}$, which equals 1 if the firm to which the establishment belongs is a for-profit firm and 0 otherwise), a variable indicating whether or not a firm was restructured (dummy variable - RESTRUCT $T_{i t}$ ) and a variable indicating whether or not the establishment belongs to a financial group (dummy variable - GROUP $i t$ ). Finally, the GROUP variable will not be retained in our estimation, as it does not have any impact on the propensity to take STC recourse. For the RESTRUCT $_{i t}$ variable, we also calculate its values lagged by one year and by two years $(t-1$ and $t-2)$.

Fifth, some additional information is obtained from the DADS files (2002-2005), which are administrative files containing data at the establishment level. We mainly collect information about employee skill sets: $N O S K I L L_{i t}$ gives the number of employees having no skills and HIGHSKILL $L_{i t}$ gives the number of highly skilled employees. We then calculate the percentages of unskilled and highly skilled employees and dummy variables corresponding to the quartiles of their distributions. Finally, we use only the first quartile from the share of unskilled employees and the fourth quartile from the share of highly skilled employees. As UNEDIC files end in 2003, the variables SIZE $_{i t}$, INDUSTRY $Y_{i t}$ and WOMEN $_{i t}$ are taken from the 2004-2005 DADS files. To control for the geographical location of the 
establishment, we introduce dummies corresponding to the eight principal French regions, according to a definition from the National French Institute of Statistics (INSEE): $R E G_{i t}^{k}$ where $k=1, \ldots, 8$.

Finally, we use the CITRUS database. It is produced by the National French Institute of Statistics and it contains firm data. CITRUS is a quasi-exhaustive dataset for listed companies and their subsidiary companies that have to release notifications of mergers, scissions and summons. Since its creation in 1998, the CITRUS file has been improved by integrating new sources of information. Nonetheless, the increase in information from the most recent period must be handled with caution. In CITRUS, the period 2000-2005 seems relatively homogenous in terms of the quality of data and firm coverage. We use this data source to control for the fact that establishment exits (identified with the SIREN file) are not due to M\&As for the period 2000-2005. In other words, for each year of the period 20002005, we check that firms to which establishments belong that disappear in $t, t+1$ or $t+2$ according to the SIREN file are not associated with M\&As ${ }^{5}$. For each M\&A in the CITRUS file, we can identify the merging company and the "absorbed company". We eliminate from our data set firms that appear as "absorbed firms" in the previous year or the year of interest (t) and disappear in $t, t+1$ or $t+2$. For example, for 2002, we eliminate establishments that, according to the SIREN file, exited in 2002, 2003 or 2004 and that belonged to firms that, according to the CITRUS source, were "absorbed" by other firms in 2002 . We do not impose any control on the type of M\&A. As we concentrate on exit phenomena, establishments belonging to merging companies on the period of analysis are not eliminated. The use of the CITRUS data source means that for each year we eliminate approximately 20,000 establishments. We have to recall that the main bias introduced by this type of check is the difference between firm and establishment data: our data are at the establishment level and we

\footnotetext{
${ }^{5}$ CITRUS gives information through 2006. For the year 2005, we cannot control for potential M\&As in 2007.
} 
eliminate establishments whose parent firms are in the process of an M\&A. Even if the quality of the information from the SIREN file is sufficiently good to identify an establishment's exit, this type of check is nevertheless necessary. Henceforward, an establishment exit means all types of activity suspension in French territory, excepting situations of M\&As (more precisely, excepting situations of "absorbed firms" in M\&As).

\section{[Insert Figure 1]}

To obtain the yearly final samples, we imposed three stages in the data cleansing process. The first stage consists of erasing establishments that are supposedly inactive, establishments that disappear before the year of interest or are created after the year of interest (for example, for the year 2002, we erased establishments that "die" before 2002 or are created after 2002). In the second stage, we eliminated establishments and firms with 0 employees in order not to have incoherent values in terms of STC use. Finally, we erased all observations with missing values for our control variables ${ }^{6}$. For the period 1995-1999, the number of establishments that exited in $t, t+1$ or $t+2$ is curiously small. This might be the consequence of the quality of data collection in the SIREN file, which seems of a better quality since 2000. For this reason, we decided to restrain our period of analysis to 20002005 .

Merging these six data sources allows us to use a very rich and original data set to study the relationship between STC and establishment exit. By merging the six databases and by imposing these data cleansing checks, we obtain a data set for each year that contains more than 550,000 observations $^{7}$. Our purpose is to analyze the effects of STC on establishment exit varying in time (in $t, t+1, t+2$ ). For example, for 2002, we study how the recourse to STC

\footnotetext{
${ }^{6}$ For continuous variables, we analyze their distributions and aberrant values. As the number of aberrant values was very small each time, we decided to work with deciles and quartiles, respectively, and in this way, avoid the influence of these aberrant values without excluding the establishments from the analysis.

${ }^{7}$ As we study the effect of STC on establishment exit, it is not possible to construct a panel of establishments. Each year, the final sample contains a different number of establishments.
} 
in 2002 affects establishment exit in 2002, 2003 and 2004 (as well as associated crosseffects). To analyze the effect of STC in 2002 on the establishment exit in 2003 or 2004, we must eliminate establishments that exit in 2002. If we do not eliminate them, we will introduce a bias, as these establishments are already "dead". For this reason, we assess each year with three different sample size files. The first file corresponds to the file obtained after merging the six data sets (sample 1). With this file, we analyze the effect of STC in $t$ on the exit indicators EO,E01 and E012. The second file is obtained by eliminating establishments that disappear in $t$ (sample 2). In this situation, we analyze the effect of STC in $t$ on the exit indicators E1 and E12. Finally, we eliminate establishments that disappear in $\mathrm{t}+1$ and we obtain the last file (sample 3), which is used for analyzing the impact of STC in $t$ on the E2 indicator.

The recourse to STC stands for a "rare phenomenon." Between 1995 and 2005, we estimated that, on average, STC concerns less than $1 \%$ of the establishments from all industries, excepting agriculture (Calavrezo et al, 2009b). Besides, between 1995 and 2005, the number of establishments that had STC authorizations significantly decreased in metropolitan France (see figure 1). Between 1996 and 2005, the number of establishments with STC authorizations diminished from 34,000 establishments to 5,000 (a fall of 85\%). For example, in 2002, approximately 7,000 establishments had STC authorizations. In our final sample for the year 2002, among our 650,000 establishments after several matching steps we identify around 3,600 establishments with STC authorizations. For this reason, we must implement an econometric strategy that takes into account the under-representation of STC recourse.

\section{The econometric strategy}


In this study, we seek to evaluate the effect of the STC recourse on establishment exit. The interest in such an analysis is very high, as Calavrezo et al. (2009a) show that STC seems to be only "postponing" redundancies. Several factors are likely to explain establishment exit, and maybe to simultaneously affect establishment exit and STC recourse, producing a selection bias. At the heart of our statistical evaluation, we must deal with the problem of selection bias. In our case, having STC authorizations is a decision that is based on the entrepreneur's choice being at least partly rational. This decision cannot be independent from the way the entrepreneur evaluates the consequences of his choice. Establishments having STC authorizations are subject to a non-random selection process (according to their economic performance, short-term downturns, and structural downturns, among others), or even an auto-selection process, if we consider that the recourse to STC is an element of their internal strategies. Not taking into account this factor can lead to biased results. On the other hand, having an STC authorization also contains a random component, as being STCauthorized depends on the department (the French county) where the entrepreneur requests authorizations from the administration (this aspect will be explained more precisely in section $6.4 .3)$

In order to analyze the effect of STC on establishment exit by controlling for the selection bias related to the STC recourse, we use propensity score models. These were initially developed by Rosenbaum and Rubin (1983) to study the efficiency of medical treatments. Since then, these models have been improved (see for example Heckman and his various co-authors) and used in economics especially to test the efficiency of training programs (for a complete survey see Heckman, Smith and Lalonde, 1999). This method consists of comparing the "health" of each establishment that receives the treatment (uses STC) with the "health" of an identical counterfactual that does not receive the treatment (does not use STC). To identify statistically the counterfactual, the approach consists of building a 
counterfactual population for which the distribution of the propensity score, calculated according to a number of observable characteristics, is the same as for the group receiving the treatment . By comparing the exit rate of establishments using STC and of counterfactuals, we can determine the impact of STC on establishment exit.

Our annual files permit us to identify two types of establishments: establishments that take recourse in $t$ to STC $(S T C=1)$ and those that do not use STC in $t(S T C=0)$. The efficiency of the treatment is measured through the result $y_{i}$. Thus each establishment has two potential results: $y_{0}$ (if $S T C=0$ ) and $y_{1}($ if $S T C=1)$. The effect of the recourse to STC on establishment exit $\left(C=y_{1}-y_{0}\right)$ is unobservable and individual (and consequently its distribution is not identifiable), as $y_{0}$ and $y_{1}$ are never observed simultaneously (because an individual is either treated or untreated, but never both at the same time). Only the "true" result (translated by the establishment exit and denoted $\mathrm{Y}$ ) is observed: $Y=y_{1} S T C+y_{0}(1-S T C)$.

$Y_{i}$ is the vector of performance variables: $Y_{i}=\left(E_{i}^{j}\right)$. The variable $E$ indicates if the establishments disappear (if they are "dead") after STC use. The index $j=0,1,2,01,12,012$ indicates the temporal window in which we calculate the effect (see Table 1 for more details). Performance variables are calculated for the six years of analysis $(t=2000, \ldots 2005)$. Only the couple $(Y, S T C)$ is observed for each establishment. However, if performance variables are independent of the assignment to the treatment, $\left(y_{0}, y_{1}\right) \perp S T C$. In other words, if the assignment to the treatment is random, then the average effect on the treated can be identified as $C_{\text {treated }}=E\left(y_{1}-y_{0} \mid S T C=1\right)$. In the majority of cases, the property of independence is invalid. A solution would be to compare the health of each individual who received the treatment with the health of an identical counterfactual who did not receive the treatment. To statistically identify the counterfactual, the approach consists of building a counterfactual 
population for which the distribution of a number of observable characteristics $(X-$ matching variables) is the same as for the group receiving the treatment. In this way we can reduce the selection bias. Consequently, the property of independence must be respected conditional to matching criteria and is less restrictive:

$$
\left(y_{0}, y_{1}\right) \perp S T C \mid X
$$

From the literature on STC and establishment exit, we retain three categories of control variables. First, we use "standard" establishment characteristics (size, industry, geographical location, age) and firm characteristics (legal status, restructuring). Second, we control for economic performance variables: the value-added variation rate in $t$ and lagged by one year ${ }^{8}$ and apparent labor productivity lagged by one year. Finally, we use variables that describe the structure of the labor force inside the establishment: the share of unskilled workers and the share of highly skilled workers, as well as the share of women.

When many matching criteria are taken into account (as in our case), finding a counterfactual can be problematic. Rubin and Rosenbaum (1983) solved this problem by showing that conditional independence with the $X$ variables was equivalent to independence compared to the propensity score, $P(X)$ :

$$
\left(y_{0}, y_{1}\right) \perp S T C \mid P(X)
$$

The propensity score constitutes a one-dimensional summary of the matching variables and estimates the probability of being exposed to the treatment, conditional on these variables.

Propensity score matching models are two-step methods. In the first step, we have to estimate the propensity score. In our case, we estimate it with a logit model and we use two different specifications (depending on the variables that are available for each year). The first model (Model A) is estimated for all the years of the period 2000-2005 and contains the

\footnotetext{
${ }^{8}$ For example, in 1998, we use the value-added variation rate calculated for 1997 (the evolution between 1996 and 1997).
} 
following explanatory variables: size, age, industry, department, percentage of women, apparent labor productivity, value-added variation rate, legal status and restructuring. The second model (Model B) is estimated for the period 2002-2005 and contains the following additional explanatory variables: percentage of unskilled workers and of highly skilled workers.

In the second step, depending on the propensity scores of treated and untreated establishments, there are several matching techniques: kernel matching, nearest-neighbor matching, radius matching and stratification matching (see Caliendo and Kopeinig, 2008 for a complete presentation of these different estimators). In our data, the number of establishments that do not use STC is very high (the control group). For example, for the year 2002, the final sample contains 650,000 establishments and approximately 3,600 establishments participate in the STC program. Thus it seems appropriate that we perform matching using the nearestneighbor method. This estimation is the most simple among propensity score matching methods, as it consists of choosing for each treated establishment the counterfactual that is the nearest in terms of the propensity score value. There are several peformance types for this method. First, nearest-neighbor matching can be performed with replacement or without replacement. In the first case, an untreated establishment can be used several times as a counterfactual. In the second case, an establishment can only be used once for the construction of the counterfactual ${ }^{9}$. There is a trade-off between bias and variance: if replacement of establishments is permitted, the average quality of the matching will increase and the bias will decrease. Then, we can use more than one establishment to construct the counterfactual (the case of "oversampling"). In this case, there is also a trade-off between bias and variance: the variance decreases (as we use more information to construct counterfactuals) and the bias increases, being the result of average matching of inferior

\footnotetext{
${ }^{9}$ In the case of nearest-neighbor matching without replacement, the estimation depends on the order in which establishments are matched. Establishments should be first randomly sorted.
} 
quality (Smith, 1997). In the case of "oversampling," one should establish first the number of partners to perform the matching and the weight affected to these partners. The method of nearest-neighbor can lead to bad quality matching if the nearest neighbor is far in terms of its propensity score value. As only $0.5 \%$ of the establishments of our sample receive the treatment, this indicates that the probability of finding a unique establishment without the treatment and with an almost identical propensity score is very high. Finally, we decide to implement nearest-neighbor matching without "oversampling" (called one-to-one matching) with replacement by restricting a maximum distance between propensity scores for the treated and their nearest neighbors (generally referred to in the economic literature as caliper) to $0.0001^{10}$. We also impose the common support condition. Standard errors are calculated with the analytical expression of the variance of the nearest-neighbor estimator. Abadie and Imbens (2006) show that calculating standard errors with bootstrap techniques cannot be done for the nearest-neighbor estimator. A common problem in evaluation papers is that the sample used is particular (Smith and Todd, 2005). For example, participants in the program are overrepresented in comparison to the number of admissible people. This problem is called "choice-based sampling" and exists in this case. In our files, the number of STC beneficiaries is very weak (less than 1\%). Heckman and Smith (1995) showed that to solve this problem, matching must be done on the odd-ratios. They also show that for matching with a unique nearest neighbor, matching on the propensity score or on the odd-ratios gives the same results. We also implement some tests that verify the quality of the matching.

To conclude, for each establishment exit variable, and for each of the two possible model specifications, we implement nearest-neighbor matching. For each sample during

\footnotetext{
${ }^{10}$ We tested several values for the caliper, but we finally choose the value 0.0001 because the values for the propensity score are very small in our case. Because of a large number of zeros associated with the recourse to STC and at the same time related to the fact that we control with categorical variables, the values of the propensity score are concentrated around 0 .
} 
period 2000-2001, we apply one matching technique and for each sample during the period 2002-2005 we apply two matching techniques.

The results

We first present some descriptive statistics based on our final samples (section 6.1). We then outline the determinants of the probability to benefit from STC authorizations (section 6.2). Section 6.3 presents the results of the econometric strategy. Section 6.4 presents the results for establishments with at least 50 employees. Finally, we test the robustness of the relationship between STC and establishment exit variables by using alternative samples and methods (section 6.5).

\subsection{Descriptive statistics}

In Table 2, we present the different files we used for each year and for the three samples. We provide a "global picture" of STC recourse and establishment exit (establishment exit variables are presented in more detail in Table 1). Each year the files include around 650,000 establishments. Among them, approximately 3,500 use STC authorizations $(0.6 \%)$ and $10-12 \%$ exit in $t, t+1$ or $t+2$ (E012 dummy variable). For example, in 2002, approximately 6\% of establishments exited by 2003 (E01 dummy variable). This statistic is consistent with figures given generally in the literature: firms' average annual exit

rate is between 5\% and 10\% (see Agarwal and Gort, 1999; Dunne et al., 1988, Baldwin and Gorecki, 1991).

\section{[Insert Table 2]}

\subsection{The determinants of STC recourse}


In the first stage of the econometric strategy, we estimate the probability of using STC authorizations in a given year with a logit model. For 2000 and 2001, we only use Model A. For the period 2002-2005, we use the two specifications: Model A and Model B (see section 5 for more details). Table 3 presents the results of the logit model only for the year 2002 (we retain only sample 1 and present the results for Model A and Model B) ${ }^{11}$. We find the same results for all the years of the study.

\section{[Insert Table 3]}

We analyze the correlation between the probability of using STC and establishments' and firms' characteristics. We use four "standard" variables: size, industry, age and geographic location.

We find quite "traditional" results in terms of STC use: the probability of benefitting from STC authorizations increases with the establishment's size (Gray, 1998). Industry dummies are strongly significant due to the sectoral dimension of STC use. Establishments from the following industries have a higher probability of benefitting from STC authorizations in comparison to the industry "education, health and social action" (which is the reference): manufacture of consumer goods, manufacture of motor vehicles, manufacture of capital equipment, manufacture of intermediate goods and the transportation industry. Regional dummies are always significant. This shows the importance of the geographical location for STC recourse. Being outside the Paris region (the "Ile-de-France" region) increases the probability of using STC in 2002. Finally, older establishments (belonging to the fourth quartile of establishment age distribution) have a higher probability of using STC, probably because of a better knowledge of the device.

\footnotetext{
11 In Appendix 1, we present the distribution of establishments' and firms' characteristics according to their use of STC for the year 2002 (sample 1 and Model B).
} 
We also introduce "standard" firm-level variables: the firm's legal status and a variable indicating whether or not a firm has been restructured. The fact that an establishment belongs to a for-profit firm is positively and significantly associated with the probability of benefitting from STC authorizations. The restructuring plans that we measure here do not involve the exit of the firm; in other words, they do not concern "absorbed companies" from M\&As (see section 4). Being restructured in 2002 decreases the probability of using STC during the year. However, being a restructured firm in 2001 increases the probability of benefitting from STC authorizations. This might be due to the fact that a restructuring in $t-1$ would involve a "negative" shock on the economic performance of the firm, involving additional requests for STC authorizations.

The economic performance of the establishment's parent firm plays a substantial role in STC use. To take into account the economic situation of the firm, we introduce the valueadded growth rate (in 2002 and 2001) and apparent labor productivity (in 2001). The introduction of these variables is absolutely necessary because STC use and establishment's exit depend strongly on the economic situation. Globally, the use of STC in $t$ decreases with the level of apparent labor productivity in $t-1$. Similarly, the probability of STC use in $t$ decreases with the value-added growth rate in $t$ and $t-1$. This negative link between good economic performances and the use of STC authorizations was evidenced by Gray (1998) and by the papers of Calavrezo et al. (2009a and b) on STC in France. Moreover, according to the law, an establishment has to prove that it is in a bad economic situation in order to benefit from STC authorizations.

The last category of variables takes into account the structure of the labor force: the share of women, as well as the share of highly skilled and unskilled workers. We find the expected results: establishments that use the least STC authorizations are those with more 
highly skilled workers. Moreover, the probability of STC use increases when the share of women is high.

To estimate correctly the effect of the use of STC on establishment exit, we must have a sufficiently large common support for propensity scores: the probability of establishments using STC and the probability of establishments not using STC have to overlap at a maximum. In our case, the distributions of propensity scores of treated and non-treated groups almost completely overlap. We check if the two models that explain STC use are well specified by implementing a test that analyzes standardized differences. This test was elaborated by Rosenbaum and Rubin (1985). It computes for each matching variable a measure of the diminution of the selection bias. It is easy to implement. It is equivalent to a test of equality of means of treated and non-treated groups, before and after matching. We compute the reduction of the bias associated with the difference of average differences before and after matching. We present the test for 2002 (sample 1, Model B) in Appendix 2. Thus we observe strong bias reductions. We conclude that variables that we introduced in the logit model determine well the probability of using STC.

\subsection{The effect of STC on establishment exit}

In the second stage of the econometric strategy, we use propensity scores previously estimated with the logit model. For each treated establishment, by comparing its propensity score, we determine a counterfactual establishment that is not treated. Then, we estimate the average effect of the treatment on the difference of means of the "performance" variable for the treated establishments and their counterfactuals. We have six "performance" variables (establishment exit variables). We only present the average effects of the treatment (STC use) on the treated establishments (the ATT effect). 
For each year and each model (Models A and B), we implement a nearest-neighbor propensity score matching with replacement, by imposing the condition that the nearest neighbor has a propensity score in a radius inferior to 0.0001 .

Regardless of what the model considers, the significance is the same with slightly different effects (Table 4). The principal result suggests that the STC does not prevent an establishment from exiting the following year (measured with the dummy variable E1): there is a significant and positive effect. For Model A, this effect takes values comprised between 0.4 and 3.6 points, according to the year of interest. For Model B, the effect varies between 1.4 and 3.3 points. For example, using Model B for 2002, the use of STC increases by 3.3 points the probability for an establishment to exit in 2003.

\section{[Insert Table 4]}

With regards to the EO dummy (the exit of the establishment during the year of interest), STC use has no effect. This can be explained by the fact that for the current year, exit variables are not as well-observed, probably because of registration deadlines for the exit. In other words, it is difficult to observe establishment exits in the current year.

Regarding the exit of the establishment two years later (E2), the effects are more "mixed": most of the time they are positive and sometimes they are equal to zero. When significant, these effects are less strong (than for E1) and at maximum they equal to 2.2 points. How can we explain this result? A priori, we expect that STC use has no effect two years later, as STC is a short-term device. Thus, firstly, the effects found on E2 can perhaps be explained by registration deadlines. Moreover, these positive effects include establishments of different sizes that do not disappear at the same pace. Large establishments take longer to disappear because of constraints on collective redundancies (see section 6.4). 
As the temporality of the relationship between STC and establishment exit is not easily grasped, cross-variables of exit (E01, E12 and E012) can provide a temporal margin to interpret the results. Our results show that the use of STC significantly increases the probability of an establishment exit. Excepting E2, the effects are larger when the "temporal dimension" is wider.

\subsection{Test on a subsample of establishments with at least 50 employees}

In this section, we want to test whether or not the demography of large establishments is the same as the demography of establishments of all sizes with regard to STC recourse. In addition, Calavrezo et al. (2009a) analyze the relationship between STC and redundancies in establishments with at least 50 employees. They find that establishments that use STC more intensively also have a larger number of redundancies. We focus on this population of establishments in order to more easily compare our results to the study of Calavrezo et al. (2009a). We present the results in Table 6 only for the year 2002. Several changes are necessary to implement this test.

\section{[Insert Table 5]}

When we focus on establishments with at least 50 employees, some industries do not use STC authorizations in 2002: energy, financial intermediation, real estate activities and the industry of education, health and social action ${ }^{12}$. We exclude these industries from the analysis. For this new population, we recalculate the quartiles for the following variables: the value-added variation rate (in 2001 and 2002), the labor productivity (in 2001 and 2002), the age of the establishment (its quartiles), the share of women and share of unskilled and highly skilled (their quartiles) workers. We work with quartiles rather than deciles, as the sample of

\footnotetext{
${ }^{12}$ In this industry, only one establishment with at least 50 employees has STC authorizations in 2002.
} 
establishments with at least 50 employees is much smaller (approximately 20,000 establishments, where only 500 are concerned with STC authorizations).

The main result of this robustness test shows no effect of STC on the E1 dummy variable but, in contrast, shows the existence of a significant positive effect on $E 2$ (the exit of the establishment in $t+2$ ). If we use the second model specification (Model B) and the estimator with replacement, where the nearest neighbor is within a radius less than 0.0001 , the effect of STC is much higher for the subsample of establishments with at least 50 employees (see Tables 5 and 6): on average, the exit of establishments with at least 50 employees using STC is higher by 4.8 points (it is 1.7 points for the initial sample).

For establishments with at least 50 employees, the relationship between STC use and the exit of establishments seems to be delayed. Behind this result lie two related aspects: an economic aspect (demography of large establishments is not the same) and a statistical aspect (on this subsample, there are fewer exits of establishments). Large firms have more substantial legal constraints. For example, a firm with at least 50 employees is obliged to implement a safeguard plan for employment if the employer wishes to dismiss at least 10 employees over a period of 30 days. Such procedures are probably more costly in terms of time when the size of the establishment is large. In addition, large firms are also involved in the development of training plans with employees, which can lengthen the time between STC use and their exit.

\subsection{Robustness tests}

To validate the robustness of our results, we do some checks by mobilizing additional samples and alternative methods.

\subsubsection{Tests with other nearest-neighbor estimators}


We implement three additional nearest-neighbor estimations in order to test whether or not the results change with replacement, without replacement, and without replacement by imposing that the nearest neighbor has the propensity score in a radius inferior to 0.0001 . Table 6 presents the results for this test, only for 2002 (a randomly chosen year).

\section{[Insert Table 6]}

For all the variants of the match, we always find the same significance with quite similar effects (see Table 6). For example, for the E012 dummy variable, the effect varies from 4.7 points for the fourth variant to 5.3 points for the first variant of the match. For the variable $E 1$, which concerns us particularly, the effects are almost identical and equal to 3.6 points for all four of the variants.

\subsubsection{Tests on subsamples constructed from French departments}

To take into account the heterogeneity of departmental behavior in terms of STC authorizations, we implement our econometric strategy on subsamples of establishments.

The methodology of propensity score matching allows us to measure the effect of STC use on establishment exit. If these effects are not biased, then STC use conditional on the retained observable characteristics must be independent of the exit of establishments. However, it is likely that unobservable characteristics influence STC use, as well as the exit of establishments. For this reason, even when conditioned on observable characteristics, there is always a suspicion that STC use is not independent of establishment exit. In section 5, we explain that considering the nature of the observed phenomena (STC use and establishment exit), it is not possible to develop models that control unobservable characteristics, such as the 
DID models with propensity score matching or regression models with endogenous regimes ${ }^{13}$. In this section, and in the next one, we set up tests to remove this uncertainty. Our test consists of implementing the initial econometric strategy on a subsample of establishments belonging to departments where STC use is more frequently authorized, and on a subsample of establishments belonging to departments where STC is less frequently authorized. A priori, given the econometric strategy and given the chosen observable characteristics, if we did not make STC use independent of establishment exit, we would get different effects for the two subsamples. However, if outcomes are significantly different from zero and positive for both subsamples, it will be a sign of a good control of the selection bias associated with STC use. Therefore, we will confirm that the estimated effects of our main econometric strategy are not biased.

An employer who wishes to use STC must necessarily make a preliminary request to the French administration at the departmental level before the implementation of STC. The authorization has a geographic dimension (French departments correspond to US counties). In this paper, we use information on what is authorized by the French administration. Calavrezo (2009) shows that within French departments, beyond a "standard" application processing system to authorize STC (analysis of order books, visits to the firm, discussions with staff representatives, and verification of prior STC requests, among others), there is a subjective approach to authorizing STC that is specific to each departmental unit. We can imagine that the way STC is authorized may differ at the departmental level, beyond, of course, the industrial structure of the departments. For this reason, we want to test whether or not our results will change if we focus on different categories of establishments, built in terms of departmental STC authorizations. We perform this test only for the year 2002 using the

13 This kind of model is alternately called a switching regression model with endogenous switching, a mover/stayer model, a Roy model or Tobit V. A first treatment of heterogeneous subsamples is due to Roy (1951). 
second model specification (Model B). To simplify the presentation of the results, we decide to present only the average effects calculated on sample 2 for the $E 1$ dummy variable and for the E12 dummy variable (establishment exit one or two years later). Because in 2002, STC cannot be authorized by two French departments, we dismiss them from the analysis. We conduct a two-stage approach.

(i) We are interested in how STC is authorized at the level of the department. Initially, we classify departments into two categories relative to the median of the proportion of establishments receiving STC authorizations in the department ${ }^{14}$ : departments where STC is authorized more intensely, i.e., at levels exceeding the median (category STC plus) and departments where STC is authorized less intensively, that is to say, in proportions equal to or below the median (category STC minus).

For each category of departments (categories STC plus and minus), we set up our econometric strategy with the same control variables as described in section 5 . The results for establishments belonging to the category STC plus and to the category STC minus are presented in Table 7.

\section{[Insert Table 7]}

For the E1 variable, we find in both cases a significant positive effect of STC on the establishment exit in 2003. In the subsample of establishments with a more intensive STC use (STC plus), the average effect is 3.5 points. On the subsample STC minus, this average effect is slightly stronger: it takes values between 3.6 and 3.9 points. What conclusions can we draw from this test? Even while working on subsamples of establishments located in departments with different STC authorization behaviors, our results remain stable. This test is a check on our ability to correctly control for selection bias associated with STC authorizations.

\footnotetext{
${ }^{14}$ This indicator is constructed according to establishments that are in our final annual samples and not according to what happens in an exhaustive way in the French economy.
} 
(ii) In a second step, we construct two other categories of establishments according to the intensity at which STC authorizations are given by the French departments between 2000 and 2005. We construct a new variable STC_plus, which equals 1 if for each year of the period 2000-2005, the department authorizes STC in larger proportions than the median share of authorizations (category STC plus 2000-2005) and the opposite variable STC_minus, which equals 1 if for each year during the period 2000-2005, the department authorizes STC at levels lower than the median share of authorizations ${ }^{15}$. We introduce the same control variables as compared to the previous case ${ }^{16}$. The results for establishments in the categories STC plus 2000-2005 and STC minus 2000-2005 are presented in Table 8.

We find the same results as in the previous robustness test: there is always a positive and significant effect. The effects are somewhat larger for the subsample of establishments STC minus 2000-2005 (between 3.8 and 4.7 points) than for establishments from the subsample STC plus 2000-2005 (between 3.1 and 3.4 points). This new test confirms once again a good control of the selection bias associated with STC use.

\section{[Insert Table 8]}

\section{$7 \quad$ Conclusion}

In this paper, we analyze the relationship between STC and establishment exit over the period 2000-2005 in France. The use of STC is not randomly distributed among establishments. Moreover, a particularly bad economic situation plays a crucial role in the decision to use STC and also in the exit of establishments. We propose a method of matching

\footnotetext{
15 The construction of these two variables is made according to establishments that are in our final annual samples and not according to what happens in an exhaustive way in the French economy.

${ }^{16}$ However, as we work with fewer departments than in the previous test, some regions (among the eight aggregated regions) are excluded from the analysis.
} 
on the propensity score that takes into account several important economic health indicators (value-added variation rate and apparent labor productivity). We consider that, conditional on establishment and firm characteristics (chosen according to the economic literature), STC use is independent of establishment exit. Thus, the average effects of STC on establishment exit indicators are not a priori biased.

Our main result points out that, considering the initial samples, having STC authorizations in the current year impacts positively and significantly the probability for an establishment to exit the market the following year. We also show the absence of a simultaneous relationship between STC use and the exit of establishments (because of registration deadlines). Our results also outline a smaller net effect of STC use on the exit of the establishment two years later. As the temporality of the relationship between STC and establishment exit is not obvious, we introduce "crossed" exit dummies (on temporal windows of different lengths) to give us more information.

By focusing on large establishments (with at least 50 employees), we again find a time lag in the link between STC use and the exit of establishments: larger establishments have a different demography.

As unobservable characteristics may affect STC use and the exit of establishments, even when controlling for a rich set of observables, there can be a suspicion that STC use is not independent of establishment exit. There can always be a doubt that establishments that use STC are also those who inherently are less likely to survive. Tests of robustness are achieved on additional subsamples of establishments and with an alternative methodology to demonstrate a good control of the selection bias. On the one hand, we implement supplementary nearest-neighbor estimators and we obtain the same results. On the other hand, we focus on subsamples of establishments with opposite behaviors in terms of STC at the departmental level. As we find the same effects for establishments belonging to departments 
with intense STC authorizations and for establishments belonging to departments with weak

STC authorizations, this confirms a good control of the selection bias.

\section{References}

ABADIE A., IMBENS G.W., 2006,"On the failure of bootstrap for matching estimators", NBER Technical Working Papers, $\mathrm{n}^{\circ} 0325$, June.

ABOWD JM., ALLAIN L., 1997, «The Washington State Short-Time Compensation

Program and its Implication for European Work Share Programs», Working paper.

ABRAHAM K.G., HOUSEMAN S.N., 1994, «Does Employment Protection Inhibit Labor

Market Flexibility? Lessons from Germany, France and Belgium» R. Blank, ed. Social Protection vs. Economic Flexibility: Is there a Trade-Off?. Chicago, University of Chicago Press.

AGARWAL R., GORT M., 1999, "The Determinants of Firm Survival", April, mimeo.

BATTISTIN E., GAVOSTO A. et RETTORE E., 2001, « Why do subsidized firms survive longer? An evaluation of a program promoting youth entrepreneurship in Italy" in Lechner M. And F. Pfeiffer eds., Econometric Evaluation of Labor Market Policies, Physica-èVerlag.

BLYTON P., 1985, Changes in Working Time : An International Review, London, Croom Helm.

BURDETT K. et WRIGHT R., 1989, «Unemployment Insurance and Short-Time Compensation: The Effects on Layoffs, Hours per Worker, and Wages », The Journal of Political Economy, Vol. 97, No. 6 (Dec.), pp. 1479-1496.

CALAVREZO O, 2009, "Entre flexibilité et sécurité: l'accompagnement des entreprises et des mobilités professionnelles. Essais empiriques de microéconométrie du marché du travail », PhD thesis, University of Orléans, November, 506 p..

CALAVREZO O., DUHAUTOIS R. et WALKOWIAK E., 2009a, "The Short-Time Compensation Program in France: an Efficient Measure against Redundancies? », Document de travail du CEE, $\mathrm{n}^{\circ} 114$.

CALAVREZO O., DUHAUTOIS R. et WALKOWIAK E., 2009b, « The Substitution of Worksharing and Short-Time Compensation in France: A Difference-in-differences Approach », Economics Bulletin, vol. 29, n 2, pp. 821-834.

CALIENDO M., KOPEINIG S., 2005, « Some Practical Guidance for the Implementation of Propensity Score Matching », IZA Discussion paper, ${ }^{\circ}$ 1588, May.

CAVES R.E., 1998, "Industrial Organization and New Findings on the Turnover and Mobility of Firms", Journal of Economic Literature, Vol. XXXVI, December, pp. 1974-1982.

DUNNE T., ROBERTS M., SAMUELSON L., 1989, « The Growth and Failure of U.S. Manufacturing Plants », Quarterly Journal of Economics, Vol ; 104, pp. 671-698.

GEROSKI P., 1995, «What do we know about entry?», International Journal of Industrial Organization, vol. 13, $\mathrm{n}^{\circ} 4$.

GRAY M., 1998, «When Might a Distressed Firm Share Work? Evidence from the ShortTime Compensation Programme in France », British Journal of Industrial relations. No. 36:1, March, pp. 43-72.

GU Q., KAROLY L.A. et ZISSIMOPOULOS J., 2008, «Small Business Assistance Programs in the United States », RAND Institute Working Paper, ${ }^{\circ} 603$, September. 
HECKMAN J., ICHIMURA H. et TODD P., 1998, « Matching as an econometric evaluation estimator », Review of Economic Studies, 65(2):261-294.

HECKMAN J., SMITH J., 1995, "Assessing the Case for Social Experiments", Journal of Economic Perspective, 9, 85-110.

HECKMAN J., SMITH J. et LALONDE R., 1999, "The Economics and Econometrics of Active Labour Market Programs" in Handbook of Labour Economics vol. III A, O.

Ashenfelter and D. Card (eds.) North Holland, Amsterdam, pp. 1865-2097.

LEUVEN E. et SIANESI B., 2003, "PSMATCH2: Stata module to perform full

Mahalanobis and propensity score matching, common support graphing, and covariate

imbalance testing". http://ideas.repec.org/c/boc/bocode/s432001.html.

MADDALA G.S., 1983, Limited-Dependent and Qualitative Variables in Econometrics, Cambridge University Press.

MORRIS S., 2007, “The impact of obesity on employment”, Labour Economics, n¹4, pp. 413-433.

NEEDELS K., NICHOLSON W., KERACHSKY, S., WALSH, S., LONDON, R., MCCANNE, D., 1997, "Evaluation of the Short-Time Compensation Programs. Final report". U.S. Department of Labor, Mathematica Policy Research and Berkeley Planning Associates.

PFEIFFER F., REIZE F., 2000, "Business start-ups by the unemployed: an econometric analysis based on firm data", Labour Economics, 7, 629-663.

RUBIN D., 1974, "Estimating causal effects of treatments in randomized and non randomized studies", Journal of Educational Psychology, 66:688-701.

RUBIN D. et ROSENBAUM P.R., 1983, «The Central Role of the Propensity Score in Observational Studies for Causal Effects », Biometrika, 70 (1), pp.41-55.

ROSENBAUM, P.R., RUBIN, D., 1985, „Constructing a Control Group Using Multivariate Matched Sampling Methods that Incorporate the Propensity Score". The American Statistician 39(1), 33-38.

ROY A., 1951, "Some Thoughts on the Distribution of Earnings", Oxford Economic Paper, 3 : 135-146.

SMITH J., TODD P., 2005, "Does Matching Overcome LaLonde's Critique of Nonexperimental Estimators?", Journal of Econometrics, 125(1-2), 305-353.

SMITH H., 1997, "Matching with Multiple Controls to Estimate Treatment Effects in Observational Studies", Sociological Methodology, n²7, pp. 325-353.

VAN AUDENRODE M.A., 1994, «Short-Time Compensation, Job Security, and Employment Contracts: Evidence from Selected OECD Countries », The Journal of Political Economy, Vol. 102, No. 1. (Feb.), pp. 76-102.

WOOLDRIDGE J., 2002, Econometric Analysis of Cross Section and Panel Data, MIT Press.

WRIGHT R., 1991, "The labour market implications of unemployment insurance and short-term compensation", Quarterly Review, Federal Reserve Bank of Minneapolis, issue Sum, p. 1-19. 
Table 1: Establishment exit dummy variables

\begin{tabular}{c|l}
\hline \hline $\begin{array}{c}\text { Dummy } \\
\text { variable }\end{array}$ & Description \\
\hline \hline$E_{i t}^{0}$ & $\begin{array}{l}\text { Dummy variable which equals to } 1 \text { if the } \\
\text { establishment exits in } t \text { and to } 0 \text { otherwise }\end{array}$ \\
\hline$E_{i t}^{1}$ & $\begin{array}{l}\text { Dummy variable which equals to } 1 \text { if the } \\
\text { establishment exits in } t+1 \text { and to } 0 \text { otherwise }\end{array}$ \\
\hline$E_{i t}^{2}$ & $\begin{array}{l}\text { Dummy variable which equals to } 1 \text { if the } \\
\text { establishment exits in } t+2 \text { and to } 0 \text { otherwise }\end{array}$ \\
\hline$E_{i t}^{01}$ & $\begin{array}{l}\text { Dummy variable which equals to } 1 \text { if the } \\
\text { establishment exits in } t \text { or } t+1 \text { and to } 0 \\
\text { otherwise }\end{array}$ \\
\hline$E_{i t}^{12}$ & $\begin{array}{l}\text { Dummy variable which equals to } 1 \text { if the } \\
\text { establishment exits in } t+1 \text { or } t+2 \text { and to } 0 \\
\text { otherwise }\end{array}$ \\
\hline$E_{i t}^{012}$ & $\begin{array}{l}\text { Dummy variable which equals to } 1 \text { if the } \\
\text { establishment exits in } t \text { or } t+1 \text { or } t+2 \text { and to } 0 \\
\text { otherwise }\end{array}$ \\
\hline \hline
\end{tabular}


Figure 1: Number of establishments with STC authorizations

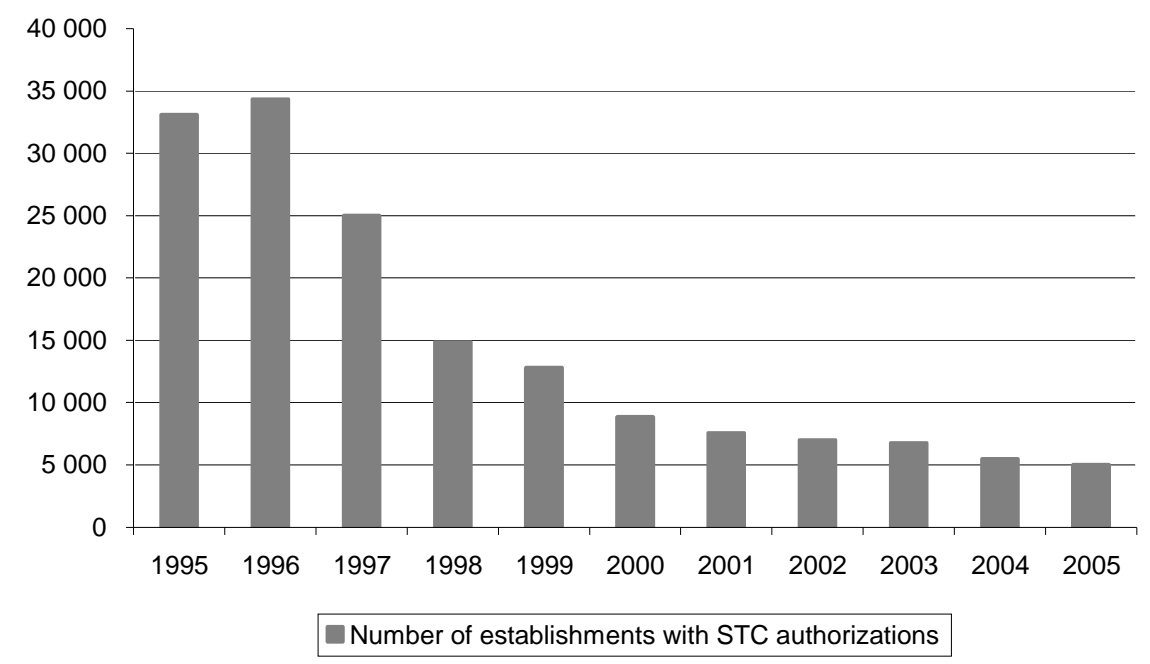

Source: Exhaustive panel of annual STC authorizations covering the period 1995 - 2005 (DARES, DDTEFP)

Field: French establishments with STC authorizations (all industries, all classes of establishment size). 
Table 2: Global statistics

\begin{tabular}{|c|c|c|c|c|c|c|c|c|c|c|c|c|}
\hline \multirow{3}{*}{$\begin{array}{l}\text { Variable } \\
\text { \% column }\end{array}$} & \multicolumn{6}{|c|}{2000} & \multicolumn{6}{|c|}{2001} \\
\hline & \multicolumn{2}{|c|}{ Sample1 } & \multicolumn{2}{|c|}{ Sample2 } & \multicolumn{2}{|c|}{ Sample3 } & \multicolumn{2}{|c|}{ Sample1 } & \multicolumn{2}{|c|}{ Sample2 } & \multicolumn{2}{|c|}{ Sample3 } \\
\hline & STC=0 & $\overline{S T C=1}$ & $\overline{S S T C=0}$ & $S T C=1$ & $\overline{S T C=0}$ & STC $=1$ & $\overline{S S T C=0}$ & $\overline{S S T C=1}$ & $S T C=0$ & $\overline{S T T C=1}$ & $\overline{S S T C=0}$ & $\overline{S S T C=1}$ \\
\hline$E O=1$ & 0.06 & 0.08 & & & & & 0.20 & 0.3 & & & & \\
\hline$E 01=1$ & 0.47 & 0.79 & & & & & 4.51 & 7.17 & & & & \\
\hline$E 012=1$ & 5.20 & 6.91 & & & & & 9.73 & 14.63 & & & & \\
\hline$E 1=1$ & & & 0.41 & 0.71 & & & & & 4.32 & 6.96 & & \\
\hline$E 12=1$ & & & 5.14 & 6.83 & & & & & 9.55 & 14.44 & & \\
\hline$E 2=1$ & & & & 4.75 & 6.16 & & & & & 5.47 & 8.04 \\
\hline Nb. est. $E 0=1$ & \multicolumn{2}{|c|}{359} & & & & & \multicolumn{2}{|c|}{1,265} & & & & \\
\hline Nb. est. E01=1 & \multirow{2}{*}{\multicolumn{2}{|c|}{$\begin{array}{c}2,676 \\
39,311\end{array}$}} & & & & & \multicolumn{2}{|c|}{28,872} & & & & \\
\hline Nb. est. E012=1 & & & & & & & \multicolumn{2}{|c|}{62,306} & & & & \\
\hline Nb. est. E1=1 & \multicolumn{4}{|c|}{2,317} & & & & & 27 , & & & \\
\hline$N b$. est. $E 12=1$ & \multicolumn{6}{|c|}{28,952} & & & 61 , & & & \\
\hline Nb. est. E2=1 & & & & & & 635 & & & & & & 34 \\
\hline Nb. est. STC $=1$ & 3,6 & & 3, & & & & 3,4 & & 3,4 & & & \\
\hline Observations & 562 & 785 & 562 & 426 & 560 & 109 & 638 & 452 & 637 & 187 & 609 & 580 \\
\hline & & & 20 & & & & & & 20 & & & \\
\hline Variable & Sam & ple1 & Sam & ole2 & San & ple3 & Sam & ole1 & Sam & "le2 & San & ole3 \\
\hline \% column & STC $=0$ & $S T C=1$ & STC $=0$ & $S T C=1$ & $S T C=0$ & $S T C=1$ & STC $=0$ & $S T C=1$ & $S T C=0$ & $S T C=1$ & $S T C=0$ & $S T C=1$ \\
\hline$E 0=1$ & 0.98 & 1.15 & & & & & 1.10 & 1.44 & & & & \\
\hline$E 01=1$ & 5.98 & 9.88 & & & & & 6.66 & 9.93 & & & & \\
\hline$E 012=1$ & 11.75 & 17.54 & & & & & 12.53 & 17.26 & & & & \\
\hline$E 1=1$ & & & 5.05 & 8.83 & & & & & 5.62 & 8.62 & & \\
\hline$E 12=1$ & & & 10.87 & 16.58 & & & & & 11.56 & 16.05 & & \\
\hline$E 2=1$ & & & & & 6.13 & 8.50 & & & & & 6.29 & 8.13 \\
\hline Nb. est. $E O=1$ & 6 & & & & & & 7,7 & & & & & \\
\hline Nb. est. E01=1 & 39 , & 523 & & & & & 46 , & 800 & & & & \\
\hline Nb. est. E012=1 & 77 , & & & & & & 88 , & 003 & & & & \\
\hline Nb. est. E1=1 & & & 33 , & & & & & & 39 , & & & \\
\hline Nb. est. $E 12=1$ & & & 71 , & & & & & & 80 , & & & \\
\hline Nb. est. E2 $=1$ & & & & & & 968 & & & & & & 203 \\
\hline Nb. est. $S T C=1$ & 3,6 & & 3, & & & & 3,7 & & 3,7 & & & 82 \\
\hline Observations & 658 & 793 & 652 & 317 & 619 & 270 & 701 & 032 & 693 & 322 & 65 & 232 \\
\hline & & & 20 & & & & & & 20 & & & \\
\hline Variable & Sam & ple1 & Sam & ole2 & San & ple3 & Sam & ple1 & Sam & ple2 & San & ple3 \\
\hline \% column & $\overline{S S T C}=0$ & $S T S C=1$ & $=S T C=0$ & STC=1 & $S T C=0$ & STC=1 & $\overline{S T T C=0}$ & STC=1 & $\overline{S T T C=0}$ & STC=1 & STC $=0$ & STC=1 \\
\hline$E O=1$ & 1.18 & 1.98 & & & & & 1.18 & 2.07 & & & & \\
\hline$E 01=1$ & 6.84 & 11.10 & & & & & 6.33 & 9.97 & & & & \\
\hline$E 012=1$ & 12.36 & 18.14 & & & & & 9.22 & 13.34 & & & & \\
\hline$E 1=1$ & & & 5.73 & 9.31 & & & & & 5.21 & 8.07 & & \\
\hline$E 12=1$ & & & 11.31 & 16.49 & & & & & 8.14 & 11.51 & & \\
\hline$E 2=1$ & & & & & 5.92 & 7.92 & & & & & 3.09 & 3.74 \\
\hline Nb. est. $E 0=1$ & 8, & & & & & & 7,8 & & & & & \\
\hline Nb. est. E01=1 & 48, & & & & & & 42 , & 137 & & & & \\
\hline Nb. est. E012=1 & 88 , & 245 & & & & & 61 , & 806 & & & & \\
\hline Nb. est. $E 1=1$ & & & 40 , & & & & & & 34 , & & & \\
\hline Nb. est. E12=1 & & & 79 & & & & & & 53 , & & & \\
\hline Nb. est. $E 2=1$ & & & & & & 343 & & & & & & 369 \\
\hline Nb. est. $S T C=1$ & 3,0 & & 2, & & & & 2,7 & & 2,7 & & & \\
\hline Observations & 712 & 603 & 704 & 173 & 663 & 701 & 669 & 107 & 661 & 220 & 626 & 670 \\
\hline
\end{tabular}

Source: Samples obtained by matching six data sets.

Field: Establishments from metropolitan France (all industries excepting agriculture and public sector). 
Table 3: The determinants of the STC recourse (2002, sample 1)

\begin{tabular}{|c|c|c|c|c|}
\hline Variable & $\begin{array}{r}\text { Mo } \\
\text { Estimate } \\
\end{array}$ & $\begin{array}{c}\text { Atandard } \\
\text { error }\end{array}$ & $\begin{array}{r}\mathrm{M} \\
\text { Estimate } \\
\end{array}$ & $\begin{array}{c}\text { Standard } \\
\text { error } \\
\end{array}$ \\
\hline $\begin{array}{l}\text { Size } \\
\text { Less than } 20 \text { employees }\end{array}$ & \multicolumn{2}{|c|}{ Ref. } & \multicolumn{2}{|c|}{ Ref. } \\
\hline $\begin{array}{l}\text { 20-49 employees } \\
50-499 \text { employees } \\
500 \text { employees and more }\end{array}$ & $\begin{array}{l}0.5634 * * * \\
1.0128 * * * \\
1.2084 * * * \\
\end{array}$ & $\begin{array}{l}0.0489 \\
0.0538 \\
0.2259 \\
\end{array}$ & $\begin{array}{l}0.5146 * * * \\
0.9552 * * * \\
1.1516 * * * \\
\end{array}$ & $\begin{array}{l}0.0501 \\
0.0553 \\
0.2265 \\
\end{array}$ \\
\hline For-profit firm & 0.1495 *** & 0.0506 & $0.1513 * * *$ & 0.0510 \\
\hline Restructuring in 2002 & $-0.7566 * * *$ & 0.2303 & $-0.7460 * * *$ & 0.2303 \\
\hline Restructuring in 2001 & $0.4049 * * *$ & 0.1354 & $0.4146 * * *$ & 0.1355 \\
\hline $\begin{array}{l}\text { Establishment age } \\
\text { 4th quartile }\end{array}$ & $0.2133 * * *$ & 0.0369 & $0.2057 * * *$ & 0.0369 \\
\hline $\begin{array}{l}\text { Geographic location } \\
\text { Ile-de-France } \\
\text { Centre North } \\
\text { Nord-Pas-de-Calais } \\
\text { East } \\
\text { North West Atlantic } \\
\text { South West } \\
\text { Centre South } \\
\text { Midi Mediterranean }\end{array}$ & $\begin{array}{l}0.9896 * * * \\
1.0476 * * * \\
0.7620 * * * \\
0.6969 * * * \\
0.6147 * * * \\
1.1340 * * * \\
1.1785 * * *\end{array}$ & $\begin{array}{l}0.0728 \\
0.0898 \\
0.0836 \\
0.0808 \\
0.0845 \\
0.0729 \\
0.0774\end{array}$ & $\begin{array}{l}0.9627 * * * \\
1.0178 * * * \\
0.7372 * * * \\
0.6744 * * * \\
0.5925 * * * \\
1.1139 * * * \\
1.1585 * * *\end{array}$ & $\begin{array}{l}0.0732 \\
0.0902 \\
0.0839 \\
0.0812 \\
0.0848 \\
0.0732 \\
0.0776\end{array}$ \\
\hline $\begin{array}{l}\text { Value added variation rate in } 2002 \\
1^{\text {st }} \text { decile } \\
2^{\text {nd }} \text { decile } \\
3^{\text {td }} \text { decile } \\
4^{\text {th }} \text { decile } \\
5^{\text {th }} \text { decile } \\
6^{\text {th }} \text { decile } \\
7^{\text {th }} \text { decile } \\
8^{\text {th }} \text { decile } \\
9^{\text {th }} \text { decile } \\
10^{\text {th }} \text { decile }\end{array}$ & $\begin{array}{l}\mathrm{I} \\
-0.5429 * * * \\
-0.9692 * * * \\
-1.0273 * * * \\
-1.1795 * * * \\
-1.5971 * * * \\
-1.6668 * * * \\
-1.6942 * * * \\
-1.7498 * * * \\
-1.5411 * * *\end{array}$ & $\begin{array}{l}0.0520 \\
0.0612 \\
0.0609 \\
0.0738 \\
0.0802 \\
0.0824 \\
0.0831 \\
0.0851 \\
0.0777\end{array}$ & $\begin{array}{l}-0.5472 * * * \\
-0.9743 * * * \\
-1.0319 * * * \\
-1.1845 * * * \\
-1.6016 * * * \\
-1.6711 * * * \\
-1.6980 * * * \\
-1.7545 * * * \\
-1.5390 * * *\end{array}$ & $\begin{array}{l}0.0521 \\
0.0612 \\
0.0609 \\
0.0738 \\
0.0802 \\
0.0824 \\
0.0831 \\
0.0850 \\
0.0777\end{array}$ \\
\hline $\begin{array}{l}\text { Value added variation rate in } 2001 \\
1^{\text {st }} \text { decile } \\
2^{\text {nd }} \text { decile } \\
3^{\text {td }} \text { decile } \\
4^{\text {th }} \text { decile } \\
5^{\text {th }} \text { decile } \\
6^{\text {th }} \text { decile } \\
7^{\text {th }} \text { decile } \\
8^{\text {th }} \text { decile } \\
9^{\text {th }} \text { decile } \\
10^{\text {th }} \text { decile } \\
\end{array}$ & $\begin{array}{l}\mathrm{I} \\
-0.1224 * * \\
-0.2016 * * * \\
-0.2372 * * * \\
-0.3449 * * * \\
-0.3027 * * * \\
-0.3408 * * * \\
-0.4660 * * * \\
-0.3523 * * * \\
-0.5161 * * * \\
\end{array}$ & $\begin{array}{l}0.0651 \\
0.0688 \\
0.0712 \\
0.0741 \\
0.0737 \\
0.0740 \\
0.0757 \\
0.0724 \\
0.0764\end{array}$ & $\begin{array}{l}-0.1306 * * \\
-0.2112 * * * \\
-0.2477 * * * \\
-0.3563 * * * \\
-0.3140 * * * \\
-0.3554 * * * \\
-0.4812 * * * \\
-0.3648 * * * \\
-0.5273 * * * \\
\end{array}$ & $\begin{array}{l}0.0651 \\
0.0688 \\
0.0712 \\
0.0742 \\
0.0738 \\
0.0741 \\
0.0758 \\
0.0725 \\
0.0765\end{array}$ \\
\hline $\begin{array}{l}\text { Apparent labor productivity in } 2001 \\
1^{\text {st }} \text { decile } \\
2^{\text {nd }} \text { decile } \\
3^{\text {rd }} \text { decile } \\
4^{\text {th }} \text { decile } \\
5^{\text {th }} \text { decile } \\
6^{\text {th }} \text { decile } \\
7^{\text {th }} \text { decile } \\
8^{\text {th }} \text { decile }\end{array}$ & $\begin{array}{l}\text { I } \\
-0.1910 * * * \\
-0.0972 \\
-0.1906 * * * \\
-0.3208 * * * \\
-0.5000 * * * \\
-0.5753 * * * \\
-0.7505 * * *\end{array}$ & $\begin{array}{l}0.0721 \\
0.0700 \\
0.0705 \\
0.0726 \\
0.0751 \\
0.0771 \\
0.0811\end{array}$ & $\begin{array}{l}-0.1900 * * * \\
-0.0939 \\
-0.1835 * * * \\
-0.3105 * * * \\
-0.4819 * * * \\
-0.5518 * * * \\
-0.7212 * * *\end{array}$ & $\begin{array}{l}0.0721 \\
0.0700 \\
0.0706 \\
0.0726 \\
0.0753 \\
0.0773 \\
0.0814\end{array}$ \\
\hline
\end{tabular}




\begin{tabular}{|c|c|c|c|c|}
\hline $\begin{array}{l}9^{\text {th }} \text { decile } \\
10^{\text {th }} \text { decile }\end{array}$ & $\begin{array}{l}-0.9623 * * * \\
-1.3672 * * *\end{array}$ & $\begin{array}{l}0.0873 \\
0.1033\end{array}$ & $\begin{array}{l}-0.9206 * * * \\
-1.3156 * * *\end{array}$ & $\begin{array}{l}0.0879 \\
0.1040\end{array}$ \\
\hline $\begin{array}{l}\text { Part of women in } 2002 \\
1^{\text {st }} \text { quartile } \\
2^{\text {nd }} \text { decile } \\
3^{\text {rd }} \text { decile } \\
4^{\text {th }} \text { quartile }\end{array}$ & $\begin{array}{l}0.2505 * * * \\
0.3696 * * * \\
0.3872 * * *\end{array}$ & $\begin{array}{l}0.0465 \\
0.0531 \\
0.0626 \\
\end{array}$ & $\begin{array}{l}0.2393 * * * \\
0.3625 * * * \\
0.3690 * * *\end{array}$ & $\begin{array}{l}0.0468 \\
0.0535 \\
0.0629\end{array}$ \\
\hline $\begin{array}{l}\text { Industry } \\
\text { Manufacture of food products } \\
\text { Manufacture of consumer goods } \\
\text { Manufacture of motor vehicles } \\
\text { Manufacture of capital equipment } \\
\text { Manufacture of intermediate goods } \\
\text { Energy } \\
\text { Construction } \\
\text { Wholesale and retail trade; repairing } \\
\text { Transportation } \\
\text { Financial intermediation } \\
\text { Real estate activities } \\
\text { Services to firms } \\
\text { Services to individuals } \\
\text { Education. health and social action }\end{array}$ & $\begin{array}{l}-0.2274 * \\
1.2365 * * * \\
1.3698 * * * \\
1.2909 * * * \\
1.8575 * * * \\
-0.0727 \\
0.0704 \\
-0.9376 * * * \\
0.3665 * * * \\
-2.4868 * * * \\
-1.7358 * * * \\
-0.2324 * * \\
-0.3932 * * *\end{array}$ & $\begin{array}{l}0.1336 \\
0.1109 \\
0.2062 \\
0.1158 \\
0.1054 \\
0.5886 \\
0.1145 \\
0.1104 \\
0.1267 \\
0.5103 \\
0.3311 \\
0.1193 \\
0.1106 \\
\end{array}$ & \begin{tabular}{|l}
$-0.3027 * *$ \\
$1.2157 * * *$ \\
$1.3265 * * *$ \\
$1.2749 * * *$ \\
$1.8131 * * *$ \\
-0.0503 \\
0.0480 \\
$-0.9800 * * *$ \\
$0.3798 * * *$ \\
$-2.3642 * * *$ \\
$-1.6984 * * *$ \\
-0.1937 \\
$-0.4712 * * *$ \\
\end{tabular} & $\begin{array}{l}0.1346 \\
0.1112 \\
0.2066 \\
0.1161 \\
0.1061 \\
0.5886 \\
0.1152 \\
0.1108 \\
0.1278 \\
0.5110 \\
0.3313 \\
0.1197 \\
0.1118 \\
\end{array}$ \\
\hline $\begin{array}{l}\text { Part of unskilled workers in } 2002 \\
1^{\text {st }} \text { quartile }\end{array}$ & & & $-0.1547 * * *$ & 0.0433 \\
\hline $\begin{array}{l}\text { Part of high-skilled workers in } 2002 \\
4^{\text {th }} \text { quartile }\end{array}$ & & & $-0.1141 * *$ & 0.0508 \\
\hline Intercept & $-5.0545 * * *$ & 0.1433 & $-4.9118 * * *$ & 0.1465 \\
\hline Pseudo $^{2}$ & \multicolumn{2}{|c|}{$\mathbf{0 . 1 6 3 7}$} & \multicolumn{2}{|c|}{0.1642} \\
\hline Observations & \multicolumn{4}{|c|}{658,793} \\
\hline
\end{tabular}


Table 4: The effect of STC on establishment exit

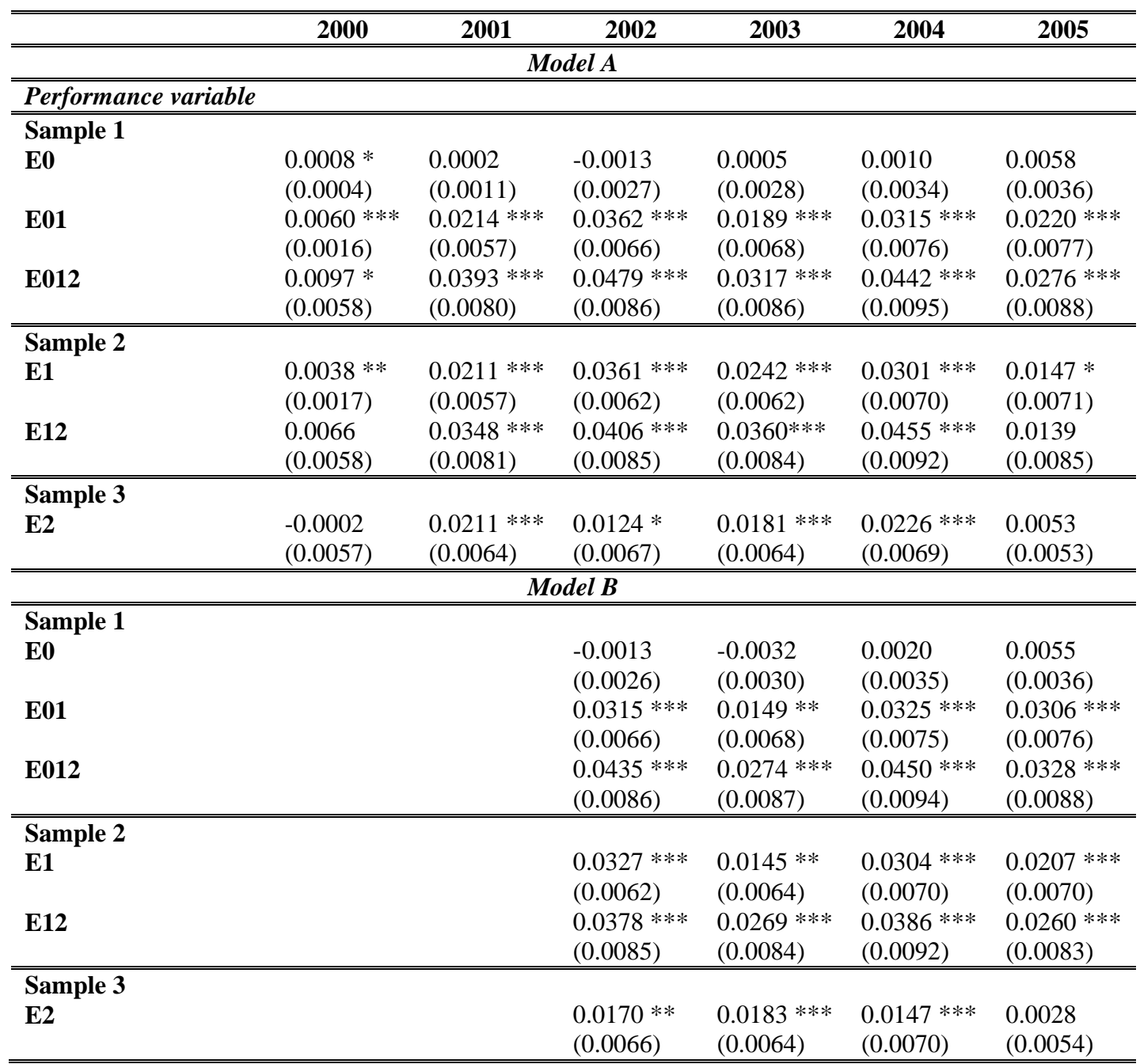

Source: Samples obtained by matching six data sets.

Field: Establishments from metropolitan France (all industries excepting agriculture and public sector).

* indicates statistical significance at the $10 \%$ level.

** indicates statistical significance at the $5 \%$ level.

*** indicates statistical significance at the $1 \%$ level. 
Table 5: Test for establishments with at least 50 employees (2002)

\begin{tabular}{|c|c|c|c|c|}
\hline $\begin{array}{c}\text { Performance } \\
\text { variable }\end{array}$ & $\begin{array}{c}\text { Without } \\
\text { replacement }\end{array}$ & $\begin{array}{c}\text { With } \\
\text { replacement }\end{array}$ & $\begin{array}{c}\text { Without } \\
\text { replacement and } \\
\text { the nearest } \\
\text { neighbor in a } \\
\text { radius }<0.0001 \\
\end{array}$ & $\begin{array}{l}\text { With replacement } \\
\text { and the nearest } \\
\text { neighbor in a } \\
\text { radius }<0.0001\end{array}$ \\
\hline \multicolumn{5}{|c|}{ Model A } \\
\hline \multicolumn{5}{|l|}{ Sample 1} \\
\hline E0 & $\begin{array}{l}-0.0054 \\
(0.0047)\end{array}$ & $\begin{array}{l}-0.0072 \\
(0.0054)\end{array}$ & $\begin{array}{l}-0.0079 \\
(0.0048)\end{array}$ & $\begin{array}{l}-0.0078 \\
(0.0057)\end{array}$ \\
\hline E01 & $\begin{array}{l}0.01073 \\
(0.0128)\end{array}$ & $\begin{array}{l}0.0107 \\
(0.0136)\end{array}$ & $\begin{array}{l}0.0020 \\
(0.0130)\end{array}$ & $\begin{array}{l}0.0039 \\
(0.0136)\end{array}$ \\
\hline E012 & $\begin{array}{l}0.0483 * * * \\
(0.0174) \\
\end{array}$ & $\begin{array}{l}0.0465 * * \\
(0.0183) \\
\end{array}$ & $\begin{array}{l}0.0376 * * \\
(0.0174) \\
\end{array}$ & $\begin{array}{l}0.0427 * * \\
(0.0184) \\
\end{array}$ \\
\hline \multicolumn{5}{|l|}{ Sample 2} \\
\hline E1 & $\begin{array}{l}0.0233 * * \\
(0.0115) \\
\end{array}$ & $\begin{array}{l}0.0215 * \\
(0.0119)\end{array}$ & $\begin{array}{l}0.0179 \\
(0.0119) \\
\end{array}$ & $\begin{array}{l}0.0156 \\
(0.0121) \\
\end{array}$ \\
\hline E12 & $\begin{array}{l}0.0664 * * * \\
(0.0163)\end{array}$ & $\begin{array}{l}0.0718 * * * \\
(0.0164)\end{array}$ & $\begin{array}{l}0.0636 * * * \\
(0.0166)\end{array}$ & $\begin{array}{l}0.0643 * * * \\
(0.0167)\end{array}$ \\
\hline \multicolumn{5}{|l|}{ Sample 3} \\
\hline E2 & $\begin{array}{l}0.0454 * * * \\
(0.0127) \\
\end{array}$ & $\begin{array}{l}0.0472 * * * \\
(0.0128) \\
\end{array}$ & $\begin{array}{l}0.0412 * * * \\
(0.0127)\end{array}$ & $\begin{array}{l}0.0469 * * * \\
(0.0128) \\
\end{array}$ \\
\hline \multicolumn{5}{|c|}{ Model B } \\
\hline \multicolumn{5}{|l|}{ Sample 1} \\
\hline E0 & $\begin{array}{l}-0.0089 \\
(0.0053)\end{array}$ & $\begin{array}{l}-0.0072 \\
(0.0058)\end{array}$ & $\begin{array}{l}-0.0101 \\
(0.0060)\end{array}$ & $\begin{array}{l}-0.0079 \\
(0.0061)\end{array}$ \\
\hline E01 & $\begin{array}{l}0.0089 \\
(0.0129)\end{array}$ & $\begin{array}{l}0.0179 \\
(0.0129)\end{array}$ & $\begin{array}{l}0.0081 \\
(0.0134) \\
\end{array}$ & $\begin{array}{l}0.0138 \\
(0.0130)\end{array}$ \\
\hline E012 & $\begin{array}{l}0.0447 * * * \\
(0.0176) \\
\end{array}$ & $\begin{array}{l}0.0572 \\
(0.0179) \\
\end{array}$ & $\begin{array}{l}0.0423 * * \\
(0.0181) \\
\end{array}$ & $\begin{array}{l}0.0511 * * * \\
(0.0180) \\
\end{array}$ \\
\hline \multicolumn{5}{|l|}{ Sample 2} \\
\hline E1 & $\begin{array}{l}0.0162 \\
(0.0120) \\
\end{array}$ & $\begin{array}{l}0.0180 \\
(0.0125) \\
\end{array}$ & $\begin{array}{l}0.0121 \\
(0.0122) \\
\end{array}$ & $\begin{array}{l}0.0157 \\
(0.0124) \\
\end{array}$ \\
\hline E12 & $\begin{array}{l}0.0575 * * * \\
(0.0167) \\
\end{array}$ & $\begin{array}{l}0.0628 * * * \\
(0.0172) \\
\end{array}$ & $\begin{array}{l}0.0544 * * * \\
(0.0173) \\
\end{array}$ & $\begin{array}{l}0.0626 * * * \\
(0.0175) \\
\end{array}$ \\
\hline \multicolumn{5}{|l|}{ Sample 3} \\
\hline E2 & $\begin{array}{l}0.03781 * * * \\
(0.0133)\end{array}$ & $\begin{array}{l}0.0416 * * * \\
(0.0136)\end{array}$ & $\begin{array}{l}0.0397 * * * \\
(0.0133)\end{array}$ & $\begin{array}{l}0.0488 * * * \\
(0.0138)\end{array}$ \\
\hline
\end{tabular}

Source: Samples obtained by matching six data sets.

Field: Establishments from metropolitan France (all industries excepting agriculture and public sector).

* indicates statistical significance at the $10 \%$ level.

** indicates statistical significance at the $5 \%$ level.

*** indicates statistical significance at the $1 \%$ level. 
Table 6: Four types of nearest-neighbor matching for 2002

\begin{tabular}{|c|c|c|c|c|}
\hline $\begin{array}{c}\text { Performance } \\
\text { variable }\end{array}$ & $\begin{array}{c}\text { Without } \\
\text { replacement }\end{array}$ & $\begin{array}{c}\text { With } \\
\text { replacement }\end{array}$ & $\begin{array}{c}\text { Without } \\
\text { replacement and } \\
\text { the nearest } \\
\text { neighbor in a } \\
\text { radius }<0.0001 \\
\end{array}$ & $\begin{array}{l}\text { With replacement } \\
\text { and the nearest } \\
\text { neighbor in a } \\
\text { radius }<0.0001\end{array}$ \\
\hline \multicolumn{5}{|c|}{ Model A } \\
\hline \multicolumn{5}{|l|}{ Sample 1} \\
\hline E0 & $\begin{array}{l}-0.0011 \\
(0.0026)\end{array}$ & $\begin{array}{l}-0.0008 \\
(0.0027)\end{array}$ & $\begin{array}{l}-0.0017 \\
(0.0026)\end{array}$ & $\begin{array}{l}-0.0014 \\
(0.0027)\end{array}$ \\
\hline E01 & $\begin{array}{l}0.0354 * * * \\
(0.0063)\end{array}$ & $\begin{array}{l}0.0368 * * * \\
(0.0066)\end{array}$ & $\begin{array}{l}0.0355 * * * \\
(0.0064)\end{array}$ & $\begin{array}{l}0.0362 * * * \\
(0.0066)\end{array}$ \\
\hline E012 & $\begin{array}{l}0.0530 * * * \\
(0.0083) \\
\end{array}$ & $\begin{array}{l}0.0499 * * * \\
(0.0087) \\
\end{array}$ & $\begin{array}{l}0.0512 * * * \\
(0.0083)\end{array}$ & $\begin{array}{l}0.0480 * * * \\
(0.0087)\end{array}$ \\
\hline \multicolumn{5}{|l|}{ Sample 2} \\
\hline E1 & $\begin{array}{l}0.0369 * * * \\
(0.0060)\end{array}$ & $\begin{array}{l}0.0364 * * * \\
(0.0062)\end{array}$ & $\begin{array}{l}0.0368 * * * \\
(0.0060)\end{array}$ & $\begin{array}{l}0.0362 * * * \\
(0.0063)\end{array}$ \\
\hline E12 & $\begin{array}{l}0.0478 * * * \\
(0.0082)\end{array}$ & $\begin{array}{l}0.0414 * * * \\
(0.0085)\end{array}$ & $\begin{array}{l}0.0464 * * * \\
(0.0083)\end{array}$ & $\begin{array}{l}0.0407 * * * \\
(0.0086)\end{array}$ \\
\hline \multicolumn{5}{|l|}{ Sample 3} \\
\hline E2 & $\begin{array}{l}0.0207 * * * \\
(0.0065) \\
\end{array}$ & $\begin{array}{l}0.0155 * * * \\
(0.0068)\end{array}$ & $\begin{array}{l}0.0180 * * * \\
(0.0065)\end{array}$ & $\begin{array}{l}0.0124 * \\
(0.0068)\end{array}$ \\
\hline \multicolumn{5}{|c|}{ Model B } \\
\hline \multicolumn{5}{|l|}{ Sample 1} \\
\hline E0 & $\begin{array}{l}-0.0016 \\
(0.0026)\end{array}$ & $\begin{array}{l}-0.0016 \\
(0.0027)\end{array}$ & $\begin{array}{l}-0.0017 \\
(0.0026)\end{array}$ & $\begin{array}{l}-0.0014 \\
(0.0027)\end{array}$ \\
\hline E01 & $\begin{array}{l}0.0296 * * * \\
(0.0065)\end{array}$ & $\begin{array}{l}0.0307 * * * \\
(0.0066)\end{array}$ & $\begin{array}{l}0.0297 * * * \\
(0.0065)\end{array}$ & $\begin{array}{l}0.0315 * * * \\
(0.0067)\end{array}$ \\
\hline E012 & $\begin{array}{l}0.0434 * * * \\
(0.0084) \\
\end{array}$ & $\begin{array}{l}0.0431 * * * \\
(0.0087) \\
\end{array}$ & $\begin{array}{l}0.0428 * * * \\
(0.0085) \\
\end{array}$ & $\begin{array}{l}0.0435 * * * \\
(0.0087) \\
\end{array}$ \\
\hline \multicolumn{5}{|l|}{ Sample 2} \\
\hline E1 & $\begin{array}{l}0.0308 * * * \\
(0.0061)\end{array}$ & $\begin{array}{l}0.03134 * * * \\
(0.0063)\end{array}$ & $\begin{array}{l}0.0312 * * * \\
(0.0062)\end{array}$ & $\begin{array}{l}0.0328 * * * \\
(0.0063)\end{array}$ \\
\hline E12 & $\begin{array}{l}0.0414 * * * \\
(0.0083) \\
\end{array}$ & $\begin{array}{l}0.0383 * * * \\
(0.0085) \\
\end{array}$ & $\begin{array}{l}0.0396 * * * \\
(0.0083) \\
\end{array}$ & $\begin{array}{l}0.0379 * * * \\
(0.0086) \\
\end{array}$ \\
\hline \multicolumn{5}{|l|}{ Sample 3} \\
\hline E2 & $\begin{array}{l}0.0204 * * * \\
(0.0065)\end{array}$ & $\begin{array}{l}0.0186 * * * \\
(0.0066)\end{array}$ & $\begin{array}{l}0.0193 * * * \\
(0.0065)\end{array}$ & $\begin{array}{l}0.0171 * * \\
(0.0066)\end{array}$ \\
\hline
\end{tabular}

Source: Samples obtained by matching six data sets.

Field: Establishments from metropolitan France (all industries excepting agriculture and public sector).

* indicates statistical significance at the 10\% level.

** indicates statistical significance at the $5 \%$ level.

*** indicates statistical significance at the $1 \%$ level. 
Table 7: Test for STC plus and STC minus establishments (2002)

\begin{tabular}{|c|c|c|c|c|}
\hline $\begin{array}{c}\text { Performance } \\
\text { variable }\end{array}$ & $\begin{array}{l}\text { Without } \\
\text { replacement }\end{array}$ & $\begin{array}{c}\text { With } \\
\text { replacement }\end{array}$ & $\begin{array}{c}\text { Without } \\
\text { replacement and } \\
\text { the nearest } \\
\text { neighbor in a } \\
\text { radius }<0.0001 \\
\end{array}$ & $\begin{array}{c}\text { With replacement } \\
\text { and the nearest } \\
\text { neighbor in a } \\
\text { radius }<0.0001\end{array}$ \\
\hline \multicolumn{5}{|c|}{ STC plus subsample / Model B } \\
\hline \multicolumn{5}{|l|}{ Sample 2} \\
\hline E1 & $\begin{array}{l}0.0359 * * * \\
(0.0069)\end{array}$ & $\begin{array}{l}0.0359 * * * \\
(0.0070)\end{array}$ & $\begin{array}{l}0.0355 * * * \\
(0.0070)\end{array}$ & $\begin{array}{l}0.0353 * * * \\
(0.0071)\end{array}$ \\
\hline E12 & $\begin{array}{l}0.0452 * * * \\
(0.0098)\end{array}$ & $\begin{array}{l}0.0472 * * * \\
(0.0100)\end{array}$ & $\begin{array}{l}0.0434 * * * \\
(0.0099)\end{array}$ & $\begin{array}{l}0.0432 * * * \\
(0.0101) \\
\end{array}$ \\
\hline \multicolumn{5}{|c|}{ STC minus subsample / Model B } \\
\hline \multicolumn{5}{|l|}{ Sample 2} \\
\hline E1 & $\begin{array}{l}0.0375 * * * \\
(0.0117)\end{array}$ & $\begin{array}{l}0.0393 * * * \\
(0.0121)\end{array}$ & $\begin{array}{l}0.0369 * * * \\
(0.012)\end{array}$ & $\begin{array}{l}0.0378 * * * \\
(0.012)\end{array}$ \\
\hline E12 & $\begin{array}{l}0.0473 \text { *** } \\
(0.0151)\end{array}$ & $\begin{array}{l}0.0446 * * * \\
(0.0155)\end{array}$ & $\begin{array}{l}0.0452 * * * \\
(0.0152)\end{array}$ & $\begin{array}{l}0.0414 * * * \\
(0.0156)\end{array}$ \\
\hline
\end{tabular}

Source: Samples obtained by matching six data sets.

Field: Establishments from metropolitan France (all industries excepting agriculture and public sector).

* indicates statistical significance at the 10\% level.

** indicates statistical significance at the $5 \%$ level.

*** indicates statistical significance at the $1 \%$ level. 
Table 8: Test for STC plus 2000-2005 and STC minus 2000-2005 establishments (2002)

\begin{tabular}{|c|c|c|c|c|}
\hline $\begin{array}{l}\text { Performance } \\
\text { variable }\end{array}$ & $\begin{array}{c}\text { Without } \\
\text { replacement }\end{array}$ & $\begin{array}{c}\text { With } \\
\text { replacement }\end{array}$ & $\begin{array}{c}\text { Without } \\
\text { replacement and } \\
\text { the nearest } \\
\text { neighbor in a } \\
\text { radius <0.0001 }\end{array}$ & $\begin{array}{l}\text { With replacement } \\
\text { and the nearest } \\
\text { neighbor in a } \\
\text { radius }<0.0001\end{array}$ \\
\hline \multicolumn{5}{|c|}{ STC plus 2000-2005 subsample / Model B } \\
\hline \multicolumn{5}{|l|}{ Sample 2} \\
\hline E1 & $\begin{array}{l}0.0312 * * * \\
(0.0010)\end{array}$ & $\begin{array}{l}0.0344 * * * \\
(0.0098)\end{array}$ & $\begin{array}{l}0.0325 * * * \\
(0.0097)\end{array}$ & $\begin{array}{l}0.0322 * * * \\
(0.0098)\end{array}$ \\
\hline E12 & $\begin{array}{l}0.0430 * * * \\
(0.0134)\end{array}$ & $\begin{array}{l}0.0445 * * * \\
(0.0137)\end{array}$ & $\begin{array}{l}0.0475 * * * \\
(0.0137)\end{array}$ & $\begin{array}{l}0.0488 * * * \\
(0.0139)\end{array}$ \\
\hline \multicolumn{5}{|c|}{ STC minus 2000-2005 subsample / Model B } \\
\hline \multicolumn{5}{|l|}{ Sample 2} \\
\hline E1 & $\begin{array}{l}0.0454 * * * \\
(0.0164)\end{array}$ & $\begin{array}{l}0.0472 * * * \\
(0.0171)\end{array}$ & $\begin{array}{l}0.0383 * * \\
(0.0166) \\
\end{array}$ & $\begin{array}{l}0.0383 * * \\
(0.0166) \\
\end{array}$ \\
\hline E12 & $\begin{array}{l}0.0544 * * \\
(0.0216)\end{array}$ & $\begin{array}{l}0.0454 * * \\
(0.0226)\end{array}$ & $\begin{array}{l}0.0479 * * \\
(0.0222)\end{array}$ & $\begin{array}{l}0.0479 * * \\
(0.0222)\end{array}$ \\
\hline
\end{tabular}

Source: Samples obtained by matching six data sets.

Field: Establishments from metropolitan France (all industries excepting agriculture and public sector).

* indicates statistical significance at the $10 \%$ level.

** indicates statistical significance at the $5 \%$ level.

*** indicates statistical significance at the $1 \%$ level. 
Appendix 1: Distribution of establishment and firm characteristics according to the STC use (year 2002 - sample 1)

\begin{tabular}{|c|c|c|}
\hline Variable & $\begin{array}{c}\text { STC }=0 \\
(\%)\end{array}$ & $\begin{array}{c}\text { STC }=1 \\
(\%)\end{array}$ \\
\hline \multicolumn{3}{|l|}{ Size } \\
\hline Less than 20 employees & 88.99 & 67.64 \\
\hline 20-49 employees & 7.34 & 16.99 \\
\hline 50-499 employees & 3.56 & 14.77 \\
\hline 500 employees and more & 0.11 & 0.60 \\
\hline \multicolumn{3}{|l|}{ Establishment age } \\
\hline $1^{\text {st }}$ quartile & 27.88 & 21.05 \\
\hline $2^{\text {nd }}$ quartile & 22.15 & 19.74 \\
\hline $3^{\text {rd }}$ quartile & 23.67 & 24.43 \\
\hline $4^{\text {th }}$ quartile & 26.30 & 34.78 \\
\hline For-profit firm & 68.42 & 82.51 \\
\hline \multicolumn{3}{|l|}{ Geographic location } \\
\hline Ile-de-France & 18.32 & 7.25 \\
\hline Centre North & 16.77 & 21.69 \\
\hline Nord-Pas-de-Calais & 5.25 & 7.05 \\
\hline East & 8.57 & 9.36 \\
\hline North West Atlantic & 13.16 & 11.03 \\
\hline South West & 11.97 & 8.81 \\
\hline Centre South & 13.27 & 21.11 \\
\hline Midi Mediterranean & 12.69 & 13.70 \\
\hline \multicolumn{3}{|c|}{ Value added variation rate in 2002} \\
\hline $1^{\text {st }}$ decile & 9.90 & 28.14 \\
\hline $2^{\text {nd }}$ decile & 9.95 & 17.81 \\
\hline $3^{\text {rd }}$ decile & 10.00 & 10.90 \\
\hline $4^{\text {th }}$ decile & 12.34 & 10.90 \\
\hline $5^{\text {th }}$ decile & 7.69 & 6.64 \\
\hline $6^{\text {th }}$ decile & 10.01 & 5.33 \\
\hline $7^{\text {th }}$ decile & 10.03 & 4.97 \\
\hline $8^{\text {th }}$ decile & 10.03 & 4.83 \\
\hline $9^{\text {th }}$ decile & 10.03 & 4.53 \\
\hline $10^{\text {th }}$ decile & 10.02 & 5.96 \\
\hline \multicolumn{3}{|c|}{ Value added variation rate in 2001} \\
\hline $1^{\text {st }}$ decile & 9.97 & 15.23 \\
\hline $2^{\text {nd }}$ decile & 9.98 & 13.26 \\
\hline $3^{\text {rd }}$ decile & 9.99 & 11.12 \\
\hline $4^{\text {th }}$ decile & 10.00 & 9.61 \\
\hline $5^{\text {th }}$ decile & 10.00 & 8.65 \\
\hline $6^{\text {th }}$ decile & 10.01 & 8.84 \\
\hline $7^{\text {th }}$ decile & 9.98 & 8.67 \\
\hline $8^{\text {th }}$ decile & 10.04 & 7.93 \\
\hline $9^{\text {th }}$ decile & 10.01 & 9.11 \\
\hline $10^{\text {th }}$ decile & 10.01 & 7.58 \\
\hline \multicolumn{3}{|c|}{ Apparent labor productivity in 2001} \\
\hline $1^{\mathrm{st}}$ decile & 9.99 & 11.58 \\
\hline $2^{\text {nd }}$ decile & 9.99 & 10.90 \\
\hline $3^{\text {rd }}$ decile & 9.99 & 13.23 \\
\hline $4^{\text {th }}$ decile & 10.16 & 13.45 \\
\hline $5^{\text {th }}$ decile & 9.81 & 12.38 \\
\hline $6^{\text {th }}$ decile & 9.89 & 10.79 \\
\hline $7^{\text {th }}$ decile & 10.11 & 9.77 \\
\hline $8^{\text {th }}$ decile & 10.01 & 8.02 \\
\hline $9^{\text {th }}$ decile & 10.01 & 6.18 \\
\hline $10^{\text {th }}$ decile & 10.04 & 3.71 \\
\hline \multicolumn{3}{|l|}{ Part of women in 2002} \\
\hline $1^{\text {st }}$ quartile & 25.01 & 23.55 \\
\hline
\end{tabular}




\begin{tabular}{|c|c|c|}
\hline $\begin{array}{l}2^{\text {nd }} \text { decile } \\
3^{\text {rd }} \text { decile } \\
4^{\text {th }} \text { quartile }\end{array}$ & $\begin{array}{l}25.02 \\
25.01 \\
24.96 \\
\end{array}$ & $\begin{array}{l}35.68 \\
24.95 \\
15.81 \\
\end{array}$ \\
\hline \multicolumn{3}{|l|}{ Part of unskilled workers in 2002} \\
\hline $1^{\text {st }}$ quartile & 37.77 & 27.64 \\
\hline $2^{\text {nd }}$ decile & 12.24 & 21.19 \\
\hline $3^{\text {rd }}$ decile & 24.95 & 34.56 \\
\hline $4^{\text {th }}$ quartile & 25.05 & 16.61 \\
\hline \multicolumn{3}{|l|}{ Part of high-skilled workers in 2002} \\
\hline $1^{\text {st }}$ quartile & 42.27 & 26.19 \\
\hline $2^{\text {nd }}$ decile & 7.78 & 15.23 \\
\hline $3^{\text {rd }}$ decile & 24.90 & 42.63 \\
\hline $4^{\text {th }}$ quartile & 25.05 & 15.95 \\
\hline \multicolumn{3}{|l|}{ Industry } \\
\hline Manufacture of food products & 4.74 & 3.24 \\
\hline Manufacture of consumer goods & 3.00 & 10.49 \\
\hline Manufacture of motor vehicles & 0.20 & 0.91 \\
\hline Manufacture of capital equipment & 2.83 & 9.28 \\
\hline Manufacture of intermediate goods & 4.81 & 33.43 \\
\hline Energy & 0.15 & 0.08 \\
\hline Construction & 14.08 & 10.38 \\
\hline Wholesale and retail trade; repairing & 31.45 & 9.58 \\
\hline Transportation & 3.73 & 4.58 \\
\hline Financial intermediation & 1.64 & 0.11 \\
\hline Real estate activities & 2.07 & 0.27 \\
\hline Services to firms & 10.28 & 5.60 \\
\hline Services to individuals & 15.48 & 8.81 \\
\hline Education. health and social action & 5.53 & 3.24 \\
\hline Restructuring in 2002 & $\mathbf{1 . 0 5}$ & 0.55 \\
\hline Restructuring in 2001 & 1.45 & 1.70 \\
\hline Observations & 655,150 & 3,643 \\
\hline
\end{tabular}


Appendix 2: Test of standardized differences (year 2002, sample 1, Model B)

\begin{tabular}{|c|c|c|c|c|c|c|}
\hline \multirow{2}{*}{ Variable } & \multirow{2}{*}{ Situation } & \multicolumn{2}{|c|}{ Mean } & \multirow{2}{*}{$\begin{array}{l}\% \text { bias } \\
\text { reduction }\end{array}$} & \multicolumn{2}{|l|}{ t-test } \\
\hline & & Treated & Untreated & & $\mathbf{p}>|t|$ & \\
\hline \multicolumn{7}{|l|}{ Size } \\
\hline \multirow[t]{2}{*}{$20-49$} & Without matching & 0.16991 & 0.07338 & & 22.22 & 0.000 \\
\hline & With matching & 0.16769 & 0.15737 & 89.3 & 1.18 & 0.236 \\
\hline \multirow[t]{2}{*}{$50-499$} & Without matching & 0.14768 & 0.03559 & & 36.15 & 0.000 \\
\hline & With matching & 0.13923 & 0.13393 & 95.3 & 0.65 & 0.513 \\
\hline \multirow[t]{2}{*}{$500+$} & Without matching & 0.00604 & 0.00114 & & 8.62 & 0.000 \\
\hline & With matching & 0.00586 & 0.00335 & 48.7 & 1.57 & 0.116 \\
\hline \multirow[t]{2}{*}{ FORPROFIT } & Without matching & 0.82514 & 0.68416 & & 18.27 & 0.000 \\
\hline & With matching & 0.82227 & 0.82227 & 100.0 & 0.00 & 1.000 \\
\hline \multirow[t]{2}{*}{ RESTRUCTt } & Without matching & 0.00549 & 0.01052 & & -2.97 & 0.003 \\
\hline & With matching & 0.00558 & 0.00586 & 94.4 & -0.16 & 0.876 \\
\hline \multirow[t]{2}{*}{ RESTRUCTt-1 } & Without matching & 0.01702 & 0.01451 & & 1.26 & 0.207 \\
\hline & With matching & 0.01674 & 0.02121 & -77.9 & -1.39 & 0.166 \\
\hline \multirow[t]{2}{*}{ QUARTILE_AGE4 } & Without matching & 0.34779 & 0.26296 & & 11.59 & 0.000 \\
\hline & With matching & 0.34431 & 0.33147 & 84.9 & 1.15 & 0.251 \\
\hline \multicolumn{7}{|l|}{ Region } \\
\hline \multirow[t]{2}{*}{ REG2 } & Without matching & 0.21685 & 0.16770 & & 7.91 & 0.000 \\
\hline & With matching & 0.21456 & 0.21289 & 96.6 & 0.17 & 0.863 \\
\hline \multirow[t]{2}{*}{ REG3 } & Without matching & 0.07055 & 0.05254 & & 4.85 & 0.000 \\
\hline & With matching & 0.07031 & 0.06473 & 69.0 & 0.94 & 0.347 \\
\hline \multirow[t]{2}{*}{ REG4 } & Without matching & 0.09360 & 0.08566 & & 1.71 & 0.088 \\
\hline & With matching & 0.09431 & 0.09096 & 57.9 & 0.49 & 0.625 \\
\hline \multirow[t]{2}{*}{ REG5 } & Without matching & 0.11035 & 0.13155 & & -3.78 & 0.000 \\
\hline & With matching & 0.11105 & 0.10798 & 85.5 & 0.42 & 0.677 \\
\hline \multirow[t]{2}{*}{ REG6 } & Without matching & 0.08811 & 0.11972 & & -5.86 & 0.000 \\
\hline & With matching & 0.08929 & 0.08789 & 95.6 & 0.21 & 0.835 \\
\hline \multirow[t]{2}{*}{ REG7 } & Without matching & 0.21109 & 0.13274 & & 13.88 & 0.000 \\
\hline & With matching & 0.20787 & 0.21038 & 96.8 & -0.26 & 0.794 \\
\hline REG8 & Without matching & 0.13698 & 0.12689 & & 1.82 & 0.068 \\
\hline & With matching & 0.13895 & 0.15067 & -16.3 & -1.41 & 0.159 \\
\hline Var_VA t & & & & & & \\
\hline DECILE2 & Without matching & 0.17815 & 0.09952 & & 15.78 & 0.000 \\
\hline & With matching & 0.17969 & 0.17941 & 99.6 & 0.03 & 0.975 \\
\hline DECILE3 & Without matching & 0.10898 & 0.1 & & 1.80 & 0.072 \\
\hline & With matching & 0.11077 & 0.1144 & 59.6 & -0.49 & 0.627 \\
\hline DECILE4 & Without matching & 0.10898 & 0.12336 & & -2.63 & 0.008 \\
\hline & With matching & 0.11049 & 0.10938 & 92.2 & 0.15 & 0.880 \\
\hline DECILE5 & Without matching & 0.06643 & 0.07688 & & -2.36 & 0.018 \\
\hline & With matching & 0.06752 & 0.06334 & 60.0 & 0.72 & 0.474 \\
\hline DECILE6 & Without matching & 0.05325 & 0.10014 & & -9.41 & 0.000 \\
\hline & With matching & 0.05413 & 0.05078 & 92.9 & 0.64 & 0.525 \\
\hline DECILE7 & Without matching & 0.04968 & 0.10029 & & -10.15 & 0.000 \\
\hline & With matching & 0.05050 & 0.05246 & 96.1 & -0.37 & 0.708 \\
\hline DECILE8 & Without matching & 0.04831 & 0.10031 & & -10.43 & 0.000 \\
\hline & With matching & 0.04911 & 0.05329 & 92.0 & -0.80 & 0.422 \\
\hline DECILE9 & Without matching & 0.04529 & 0.10028 & & -11.03 & 0.000 \\
\hline & With matching & 0.04604 & 0.04799 & 96.4 & -0.39 & 0.696 \\
\hline DECILE10 & Without matching & 0.05957 & 0.10022 & & -8.16 & 0.000 \\
\hline & With matching & 0.06055 & 0.05776 & 93.1 & 0.50 & 0.617 \\
\hline
\end{tabular}




\begin{tabular}{|c|c|c|c|c|c|}
\hline \multicolumn{6}{|l|}{ Var_Va t-1 } \\
\hline \multirow[t]{2}{*}{ DECILE2 } & Without matching & 0.13258 & 0.09982 & & 6.570 .000 \\
\hline & With matching & 0.13253 & 0.14593 & 59.1 & $\begin{array}{ll}-1.64 & 0.102 \\
\end{array}$ \\
\hline \multirow[t]{2}{*}{ DECILE3 } & Without matching & 0.11117 & 0.09995 & & 2.250 .024 \\
\hline & With matching & 0.11077 & 0.11161 & 92.5 & -0.110 .910 \\
\hline \multirow[t]{2}{*}{ DECILE4 } & Without matching & 0.09607 & 0.10005 & & $\begin{array}{ll}-0.80 & 0.425\end{array}$ \\
\hline & With matching & 0.09682 & 0.09319 & 8.7 & $\begin{array}{ll}0.52 & 0.601 \\
\end{array}$ \\
\hline \multirow[t]{2}{*}{ DECILE5 } & Without matching & 0.08647 & 0.10004 & & -2.720 .006 \\
\hline & With matching & 0.08705 & 0.0784 & 36.3 & $1.33 \quad 0.184$ \\
\hline \multirow[t]{2}{*}{ DECILE6 } & Without matching & 0.08839 & 0.10006 & & -2.340 .019 \\
\hline & With matching & 0.08956 & 0.09319 & 68.9 & $-0.53 \quad 0.594$ \\
\hline \multirow{2}{*}{ DECILE7 } & Without matching & 0.08674 & 0.09981 & & $\begin{array}{ll}-2.63 & 0.009\end{array}$ \\
\hline & With matching & 0.08622 & 0.08231 & 70.1 & $\begin{array}{lll}0.60 & 0.552 \\
\end{array}$ \\
\hline \multirow[t]{2}{*}{ DECILE8 } & Without matching & 0.07933 & 0.10038 & & -4.220 .000 \\
\hline & With matching & 0.08064 & 0.08092 & 98.7 & $-0.04 \quad 0.965$ \\
\hline \multirow[t]{2}{*}{ DECILE9 } & Without matching & 0.09113 & 0.10012 & & $\begin{array}{ll}-1.80 & 0.071\end{array}$ \\
\hline & With matching & 0.09208 & 0.09905 & 22.4 & $-1.00 \quad 0.315$ \\
\hline \multirow[t]{2}{*}{ DECILE10 } & Without matching & 0.07576 & 0.10006 & & -4.880 .000 \\
\hline & With matching & 0.07645 & 0.07478 & 93.1 & $0.27 \quad 0.789$ \\
\hline \multicolumn{6}{|l|}{ LP t-1 } \\
\hline \multirow[t]{2}{*}{ DECILE2 } & Without matching & 0.10898 & 0.09994 & & 1.810 .070 \\
\hline & With matching & 0.10854 & 0.11328 & 47.5 & $-0.64 \quad 0.523$ \\
\hline \multirow[t]{2}{*}{ DECILE3 } & Without matching & 0.13231 & 0.09989 & & 6.500 .000 \\
\hline & With matching & 0.13030 & 0.13309 & 91.4 & $-0.35 \quad 0.727$ \\
\hline \multirow[t]{2}{*}{ DECILE4 } & Without matching & 0.13450 & 0.10158 & & 6.550 .000 \\
\hline & With matching & 0.13421 & 0.12444 & 70.3 & $1.23 \quad 0.218$ \\
\hline \multirow[t]{2}{*}{ DECILE5 } & Without matching & 0.12380 & 0.09808 & & 5.200 .000 \\
\hline & With matching & 0.12388 & 0.12137 & 90.2 & 0.320 .746 \\
\hline \multirow[t]{2}{*}{ DECILE6 } & Without matching & 0.10788 & 0.09891 & & $\begin{array}{ll}1.81 & 0.071\end{array}$ \\
\hline & With matching & 0.10854 & 0.11691 & 6.7 & $-1.12 \quad 0.263$ \\
\hline \multirow[t]{2}{*}{ DECILE7 } & Without matching & 0.09772 & 0.10106 & & $-0.67 \quad 0.505$ \\
\hline & With matching & 0.09794 & 0.10435 & -92.4 & $\begin{array}{rr}-0.90 & 0.368 \\
\end{array}$ \\
\hline \multirow[t]{2}{*}{ DECILE8 } & Without matching & 0.08015 & 0.10011 & & $\begin{array}{ll}-4.00 & 0.000\end{array}$ \\
\hline & With matching & 0.08119 & 0.08147 & 98.6 & $-0.04 \quad 0.966$ \\
\hline \multirow[t]{2}{*}{ DECILE9 } & Without matching & 0.06176 & 0.10015 & & $\begin{array}{ll}-7.70 & 0.000\end{array}$ \\
\hline & With matching & 0.06250 & 0.0639 & 96.4 & $\begin{array}{rr}-0.24 & 0.808 \\
\end{array}$ \\
\hline \multirow[t]{2}{*}{ DECILE10 } & Without matching & 0.03706 & 0.10041 & & $\begin{array}{ll}-12.71 & 0.000\end{array}$ \\
\hline & With matching & 0.03767 & 0.03627 & 97.8 & 0.310 .754 \\
\hline Women $\mathrm{t}$ & & & & & \\
\hline QUARTILE2 & Without matching & 0.35685 & 0.25019 & & 14.810 .000 \\
\hline & With matching & 0.35770 & 0.36551 & 92.7 & $\begin{array}{ll}-0.69 & 0.491 \\
\end{array}$ \\
\hline QUARTILE3 & Without matching & 0.24952 & 0.25009 & & $\begin{array}{ll}-0.08 & 0.937\end{array}$ \\
\hline & With matching & 0.24498 & 0.23884 & -977.5 & $\begin{array}{lll}0.61 & 0.544\end{array}$ \\
\hline QUARTILE4 & Without matching & 0.15811 & 0.24958 & & $\begin{array}{ll}-12.73 & 0.000\end{array}$ \\
\hline & With matching & 0.15960 & 0.15765 & 97.9 & $\begin{array}{ll}0.23 & 0.821 \\
\end{array}$ \\
\hline Industry & & & & & \\
\hline SECT1 & Without matching & 0.03239 & 0.04743 & & -4.260 .000 \\
\hline & With matching & 0.03292 & 0.03209 & 94.4 & $0.20 \quad 0.842$ \\
\hline SECT2 & Without matching & 0.10486 & 0.03004 & & 26.220 .000 \\
\hline & With matching & 0.10603 & 0.09403 & 84.0 & $\begin{array}{ll}1.69 & 0.091 \\
\end{array}$ \\
\hline SECT3 & Without matching & 0.00906 & 0.00197 & & 9.540 .000 \\
\hline & With matching & 0.00921 & 0.00837 & 88.2 & $0.38 \quad 0.704$ \\
\hline SECT4 & Without matching & 0.09278 & 0.02835 & & 23.240 .000 \\
\hline
\end{tabular}




\begin{tabular}{|c|c|c|c|c|c|}
\hline & With matching & 0.09375 & 0.08817 & 91.3 & $\begin{array}{lll}0.82 & 0.411 \\
\end{array}$ \\
\hline \multirow[t]{2}{*}{ SECT5 } & Without matching & 0.33434 & 0.04806 & & 79.710 .000 \\
\hline & With matching & 0.32450 & 0.34542 & 92.7 & $\begin{array}{ll}-1.88 & 0.061 \\
\end{array}$ \\
\hline \multirow[t]{2}{*}{ SECT6 } & Without matching & 0.00082 & 0.00149 & & -1.040 .300 \\
\hline & With matching & 0.00084 & 0.00056 & 57.8 & $0.45 \quad 0.655$ \\
\hline \multirow[t]{2}{*}{ SECT7 } & Without matching & 0.10376 & 0.14083 & & -6.420 .000 \\
\hline & With matching & 0.10547 & 0.10575 & 99.2 & $-0.04 \quad 0.969$ \\
\hline \multirow[t]{2}{*}{ SECT8 } & Without matching & 0.09580 & 0.31446 & & -28.390 .000 \\
\hline & With matching & 0.09738 & 0.101 & 98.3 & -0.510 .608 \\
\hline \multirow[t]{2}{*}{ SECT9 } & Without matching & 0.04584 & 0.0373 & & 2.710 .007 \\
\hline & With matching & 0.0466 & 0.05636 & -14.4 & $\begin{array}{ll}-1.87 & 0.061 \\
\end{array}$ \\
\hline \multirow[t]{2}{*}{ SECT10 } & Without matching & 0.0011 & 0.01642 & & $\begin{array}{ll}-7.28 & 0.000\end{array}$ \\
\hline & With matching & 0.00112 & 0.00056 & 96.4 & $0.82 \quad 0.414$ \\
\hline \multirow[t]{2}{*}{ SECT11 } & Without matching & 0.00274 & 0.02074 & & $\begin{array}{ll}-7.62 & 0.000\end{array}$ \\
\hline & With matching & 0.00279 & 0.00195 & 95.3 & $0.73 \quad 0.466$ \\
\hline \multirow[t]{2}{*}{ SECT12 } & Without matching & 0.05600 & 0.10279 & & -9.280 .000 \\
\hline & With matching & 0.05692 & 0.04576 & 76.1 & $2.14 \quad 0.032$ \\
\hline \multirow[t]{2}{*}{ SECT13 } & Without matching & 0.08811 & 0.15483 & & -11.110 .000 \\
\hline & With matching & 0.08956 & 0.0971 & 88.7 & $-1.10 \quad 0.273$ \\
\hline \multicolumn{6}{|c|}{ Unskilled workers } \\
\hline \multirow[t]{2}{*}{ QUARTILE 1} & Without matching & 0.27642 & 0.37768 & & -12.580 .000 \\
\hline & With matching & 0.28041 & 0.27902 & 98.6 & $0.13 \quad 0.895$ \\
\hline \multicolumn{6}{|l|}{$\begin{array}{l}\text { High-skilled } \\
\text { workers }\end{array}$} \\
\hline \multirow[t]{2}{*}{ QUARTILE 4} & Without matching & 0.15948 & 0.2505 & & -12.650 .000 \\
\hline & With matching & 0.162110 & $\begin{array}{ll}0 & 0.15151\end{array}$ & 88.4 & $\begin{array}{ll}1.23 & 0.217\end{array}$ \\
\hline
\end{tabular}

